Keywords: WTP, Shielded

Cells, Sludge, Hydrogen

Retention: Permanent

\title{
Evaluation of Methods to Measure Hydrogen Generation Rate in a Shielded Cell Environment and a Method Recommendation
}

M. E. Stone

October 2012

Savannah River National Laboratory Savannah River Nuclear Solutions, LLC Aiken, SC 29808

Prepared for the U.S. Department of Energy under contract number DE-AC09-08SR22470. 
This work was prepared under an agreement with and funded by the U.S. Government. Neither the U.S. Government or its employees, nor any of its contractors, subcontractors or their employees, makes any express or implied:

1. warranty or assumes any legal liability for the accuracy, completeness, or for the use or results of such use of any information, product, or process disclosed; or

2. representation that such use or results of such use would not infringe privately owned rights; or

3. endorsement or recommendation of any specifically identified commercial product, process, or service.

Any views and opinions of authors expressed in this work do not necessarily state or reflect those of the United States Government, or its contractors, or subcontractors.

\section{Printed in the United States of America}

Prepared for

U.S. Department of Energy 
SRNL-STI-2012-00511

Revision 0

\section{REVIEWS AND APPROVALS}

\section{AUTHORS:}

M. E. Stone, Process Technology Programs

Date

TECHNICAL REVIEW:

C. L. Crawford, Process Technology Programs

Date

J. L. Steimke, Engineering Development Laboratory

Date APPROVALS:

D. J. Adamson, SRNL WTP Qualification Program Lead

Date Process Technology Programs

C. C. Herman, Manager

Date

Process Technology Programs

S. L. Marra, Manager

Date

Environmental \& Chemical Process Technology Research Programs 


\section{TABLE OF CONTENTS}

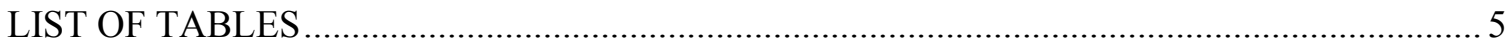

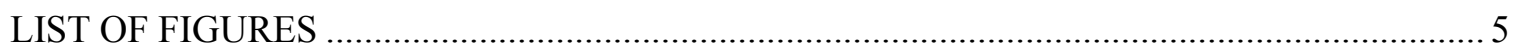

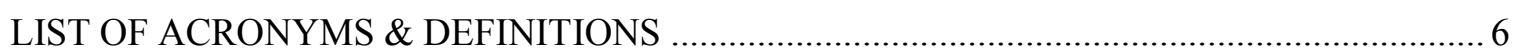

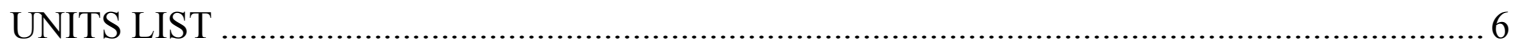

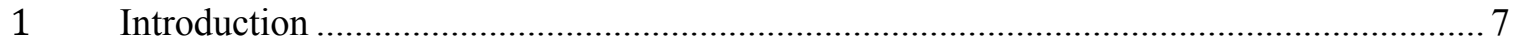

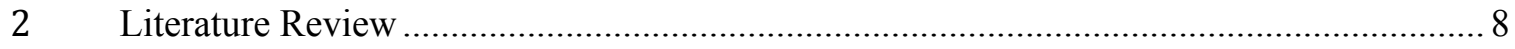

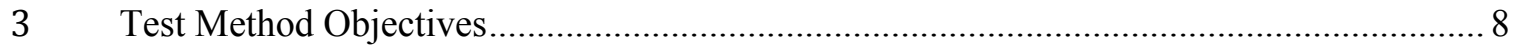

4 Evaluation of Hanford 222-S Laboratory Hydrogen Measurement Method....................... 9

5 Review of methods to generate, collect, and analyze gas sample .................................. 10

5.1 Generation and Collection of Gas Samples ............................................................... 10

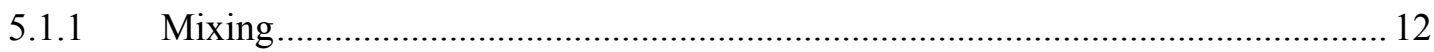

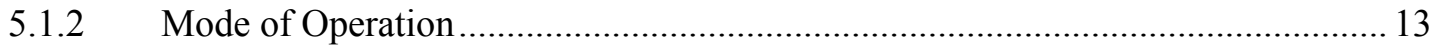

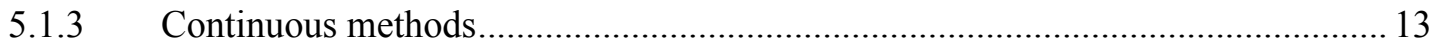

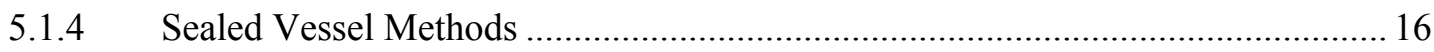

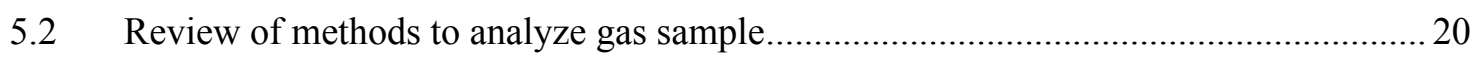

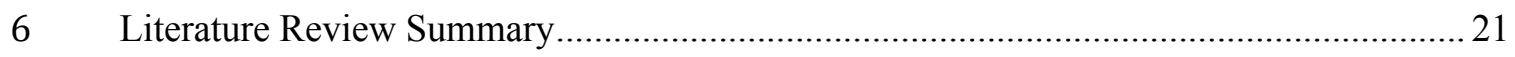

$7 \quad$ Recommended Method to Measure Hydrogen Generation Rate .......................................... 21

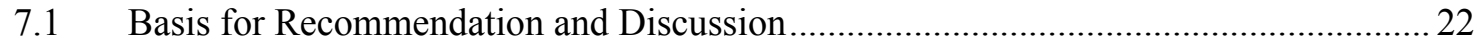

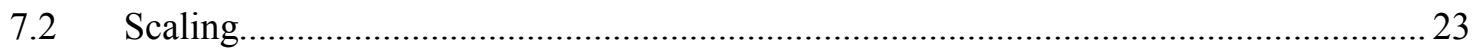

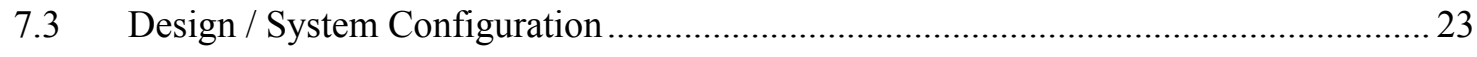

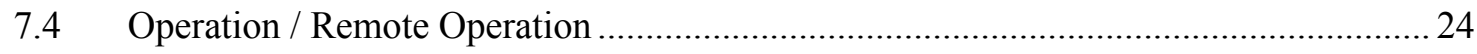

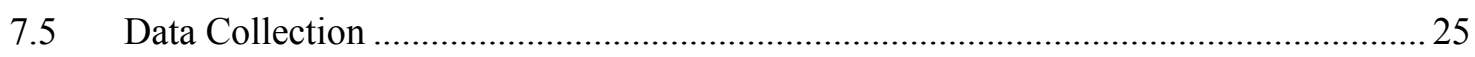

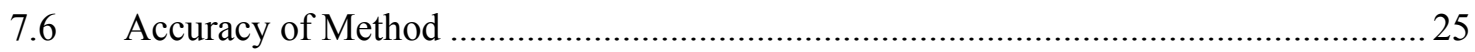

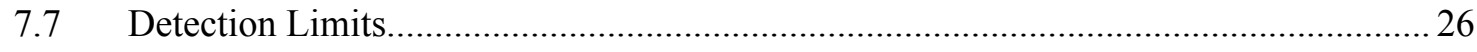

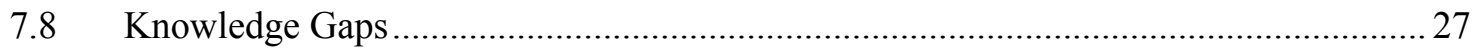

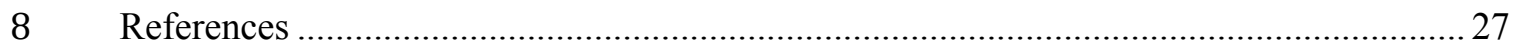

Appendix A: Documents Included in the Literature Review .................................................... 32

Appendix B: Reviewed Documents Excluded from Evaluation................................................ 40

Appendix C. Review of HGR Models for Tank Waste and Process Streams................................. 43

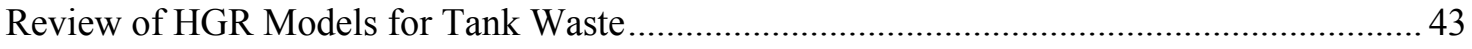

Review of Applicability of HGR Models for WTP Process Streams ......................................... 47 


\section{LIST OF TABLES}

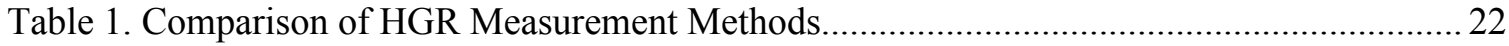

Table 2. Detection Limits for Continuously Purged System ...................................................... 26

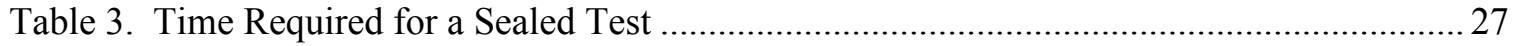

\section{LIST OF FIGURES}

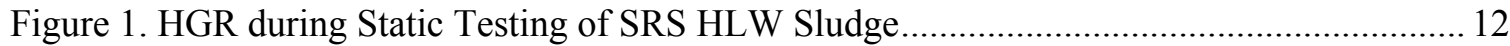

Figure 2. Continuously Purged HGR Apparatus used during DWPF Process Slurry Testing (pictured during water testing) ..................................................................................... 15

Figure 3. Continuously Purged and Agitated Apparatus for HGR Measurements ........................ 16

Figure 4. Sealed Vessel Apparatus used by PNNL for HGR Head Space Sample Preparation .... 18

Figure 5. Photograph of Sealed Vessel used during PNNL HGR Measurements ....................... 18

Figure 6. HGR Vessels During Testing ................................................................................. 19

Figure 7. Sealed Vessels used in PNNL Study of Impact of Mixing ........................................... 20 


\section{LIST OF ACRONYMS \& DEFINITIONS}

$\begin{array}{ll}\text { DWPF } & \text { Defense Waste Processing Facility } \\ \text { GC } & \text { Gas Chromatograph } \\ \text { HGR } & \text { Hydrogen Generation Rate } \\ \text { HLW } & \text { High Activity Waste } \\ \text { LAW } & \text { Low Activity Waste } \\ \text { LFL } & \text { Lower Flammability Limit } \\ \text { NFPA } & \text { National Fire Protection Association } \\ \text { PNNL } & \text { Pacific Northwest National Laboratory } \\ \text { SRNL } & \text { Savannah River National Laboratory } \\ \text { SRS } & \text { Savannah River Site } \\ \text { SS } & \text { Stainless Steel } \\ \text { UF } & \text { Ultrafiltration } \\ \text { WTP } & \text { Hanford Tank Waste Treatment and Immobilization Plant }\end{array}$

\section{UNITS LIST}

$\begin{array}{ll}\mathrm{C} & \text { Celsius } \\ \mathrm{cm} & \text { Centimeter } \\ \mathrm{F} & \text { Fahrenheit } \\ \text { gmol } & \text { Gram moles } \\ \text { gmol/L-hr } & \text { Gram moles per liter per hour } \\ \mathrm{Hr} & \text { Hour } \\ \mathrm{L} & \text { Liter } \\ \mathrm{ml} & \text { milliliter } \\ \mathrm{ppm} & \text { Parts per million } \\ \mathrm{sccm} & \text { Standard cubic centimeters per minute }\end{array}$


SRNL-STI-2012-00511

Revision 0

\section{Introduction}

The purpose of this document is to describe the current state of the art for determination of hydrogen generation rates of radioactive slurries and solutions to provide a basis for design, fabrication, testing, and implementation of a measurement method for Hydrogen Generation Rate (HGR) during qualification of waste feeds for the Hanford Waste Treatment and Immobilization Plant (WTP). The HGR measurement will be performed on samples of the Low Activity Waste (LAW) and High Level Waste (HLW) staged waste feeds for the WTP as well as on samples from selected unit operations testing during the qualification program.

SRNL has performed a review of techniques utilized to measure HGR of high level radioactive waste slurries, evaluated the Hanford 222-S Laboratory method for measurement of hydrogen, and reviewed the hydrogen generation rate models for Hanford waste. These tasks were completed in accordance with the scope of work in Tasks 1 and 3 of SCT-M0SRV00028-00-012, Inter-Entity Work Order MSOSRV00028 Task 12. Specifically, in Task 1 SRNL was requested to perform literature search " to identify and review documents to support establishment of unit operations test apparatus scaling factors and identification of key process parameters that would be used during waste qualification." The literature search was required to address, "scaling, design, and operation of unit operations test apparatus and experimental setup, including configuration, data collection, and remote handling". Task 3 required SRNL to review the Hanford 222-S Laboratory method to measure hydrogen generation rate, and make recommendations regarding its usefulness during waste qualification activities. These task objectives are closely related and have been combined into this report.

HGR from waste staged for delivery to the WTP is necessary to ensure that the waste acceptance limits for hydrogen generation are not exceeded. Models of hydrogen generation from the waste have been developed to allow calculation of expected hydrogen generation as a function of tank composition and temperature, but physical measurement of the hydrogen generation rate has been specified as the method to be used by WTP during waste qualification. Measurement of HGR is not performed during feed qualification for the Defense Waste Processing Facility (DWPF) at Savannah River Site (SRS) as the HGR models are deemed adequate.

The measurement of hydrogen generation rate can be divided into two steps. The first step is generation and collection of the headspace gas for analysis. The second step is the analysis of the gas collected. The first step has typically been performed by placing the sample to be analyzed in a sealed vessel and allowing hydrogen to accumulate for a period of time. A headspace gas sample is then extracted for analysis. A continuous flow system with online gas analysis has also been used to both generate the gas sample and perform the required analysis. The second step, analysis of the head space gas has been performed by collecting the gas sample and analyzing by gas chromatography, mass spectroscopy and other instruments.

Based on the literature review, method evaluation, and SRNL experience with measuring hydrogen generation rate, SRNL recommends that a continuous flow system with online gas analysis be used as the HGR measurement method during waste qualification. 


\section{Literature Review}

This review encompasses a review of the Hanford 222-S Laboratory procedure for HGR measurements [McCluskey, 2011], methods to generate required gas samples, gas analysis methods, and HGR models. It should be noted that a large body of work exists on hydrogen generation in HLW. This review focused on laboratory methods to measure HGR that have been used on samples of radioactive slurries.

The primary criteria for inclusion of documents in the review were (1) a description of experimental techniques used to measure the hydrogen generation rate of high level nuclear waste and/or simulants of nuclear waste and (2) documents that discussed calculation of hydrogen generation rates from Hanford tank waste composition data. The results of the HGR model correlation review are documented in Appendix C.

As stated in the document search criteria, a large body of work exists covering hydrogen generation rates in high level radioactive waste. In particular, SRNL and others have extensively studied hydrogen generation during DWPF pretreatment both with simulated wastes and with tank samples in hot cells. This work was not cited in this review because the catalytic hydrogen noted during the DWPF process is orders of magnitudes higher than the WTP Action Limits for hydrogen and sample volumes used during HGR determination are also typically much higher than expected for WTP waste qualification. It is noted that the continuous flow method used by SRNL and described in this document was based on the methods used during DWPF process studies; the documents from those studies are cited.

Documents reviewed but not included as part of this evaluation are listed in Appendix B. These documents typically discuss measurement of HGR in simulants versus radioactive tests and were excluded because they did not contain information supplemental to the radioactive tests (such as data in the impact of temperature on the measurements) or they were summary documents that did not contain information on the experimental methods.

\section{Test Method Objectives}

The objectives of the test method are enumerated below.

1. The same apparatus will be used to evaluate HGR of samples of staged LAW and HLW staged feeds.

This objective requires the test apparatus to be versatile enough to perform testing on supernate as well as slurry samples and be capable of measuring hydrogen generation rates expected from either system. The mixing of slurries will require a mechanical agitator; the design will provide for mixer speed adjustment to allow mixing of LAW samples without excessive vortex formation and splatter. The expected amount of hydrogen generated during the test will be significantly different between the staged LAW and HLW feed samples, adjustment of air purge rates can be used if necessary to keep the hydrogen concentration in range of the analytical instruments. If a sealed system is utilized, adjustment of the test duration can be used to ensure the hydrogen concentration is within range of the analytical instruments.

2. The working volume will be $100 \mathrm{ml}$ or less 
The working volume impacts the ability of the apparatus to mix the sample, the absolute amount of hydrogen generated, the amount of settled solids present, and the operational cost of the equipment.

A sealed test without mixing capability could use a working volume smaller than $100 \mathrm{ml}$. Testing with mixing capability has used volumes as low as $75 \mathrm{ml}$; therefore $100 \mathrm{ml}$ is deemed sufficient from the perspective of mixing. If mixing capability is incorporated into the test apparatus, settled solids will not be a factor in the testing.

Hydrogen is assumed to be uniformly generated in the waste as a result of chemical reactions of organics as well as radiolysis of the organics and water. A larger working volume increases the absolute amount of hydrogen generated and makes detection of small generation rates more assured. Thus, a larger sample size decreases the detection limit of the testing. Testing using continuous systems has been performed with as little as $100 \mathrm{ml}$, therefore this test volume was deemed sufficient for the continuous system.

3. Detection limits need to indicate within analytical uncertainty that the HGR limits are not exceeded versus using a $10 \mathrm{X}$ factor below the detection limit

A calculation technique exists to determine the HGR of Hanford tank waste and WTP process streams. The measurements specified in the waste qualification plan will validate that the HGR action limits identified in the waste acceptance criteria are not exceeded, but the detection limits will not be 10X below these action limits for the staged LAW feed samples. It is assumed that the measurement of hydrogen generation rate will be sufficiently accurate if the results indicate within analytical uncertainty that the action limits are not exceeded. Therefore, if the method is accurate $+/-30 \%$, then the measured result must be $30 \%$ below the HGR action limit.

It should be noted that the HGR for some samples is expected to be below the detection limit of a continuous system. Lowering the purge rate could increase sensitivity, but would make the technique more prone to errors. For sealed systems, the test duration can be adjusted to measure lower rates but the test duration to detect the HGR from some samples may be too long to be practical.

\section{Evaluation of Hanford 222-S Laboratory Hydrogen Measurement Method}

The Hanford 222-S Laboratory procedure [McCluskey, 2011] for determination of hydrogen, helium, and methane was reviewed. It should be noted that the procedure only addresses the analysis portion of the measurement of HGR from a head space sample and does not describe methods needed to generate this gas sample from the waste qualification samples. The calibration curve specified started at $25 \mathrm{ppm}$.

The procedure describes method detection and uncertainty studies with the "Kirk" gas chromatograph, preparation of standards, calibration of the GC, operation of the GC, and performing sample analysis. The "Kirk" instrument is an Agilent 6890 GC fitted with a Thermal Conductivity Detector. A 15 foot stainless steel column from Supelco packed with Carboxen 1000 was used for the method detection and 
uncertainty testing, but a 30 foot Alltech stainless steel column packed with HayeSep DB was listed as well.

Standards were prepared at different dilutions by injecting known amounts of the stock standards from a gas tight syringe into a second syringe filled with $20 \mathrm{ml}$ of nitrogen. The theory is that as the stock solution is injected up into the second syringe through the open needle that "an equal volume of nitrogen escapes". The second syringe is capped after the stock injection and mixed by inverting several times. This same dilution method is used if dilution of a process sample is needed prior to performing sample analysis.

Calibration curve fitting can be performed by four different methods: Averaged response factors fit, linear regression fit, weighted linear regression fit, or quadratic fit. Correlation factors for the fit selected as required to be equal to or greater than 0.990 . The minimum standard prepared for the calibration curve is $25 \mathrm{ppm}$ hydrogen and the calibration extends to $1500 \mathrm{ppm}$. Process samples are analyzed along with the samples needed for instrument calibration and method detection limits. A data report is prepared and peer reviewed for each sample set.

Since the method was developed for application to tank vapor samples, the instructions specify that the gas samples are generated in the tank farm using Summa canisters. This method would be applicable if it is revised to reflect samples originating from the waste qualification work. No issues were noted with the analytical methods described by the procedure, although the sample dilution method utilized requires careful execution. Use of gas sampling bulbs to perform the dilutions would be less prone to error but would also create more waste.

The detection limit of the 222-S Laboratory method is adequate if a sealed vessel is used to generate the gas sample because the concentration of hydrogen in the head space sample is a function of time and could be adjusted as needed to fit the calibrated region of the method. As described below, the staged LAW feed HGR Action Limit would result in hydrogen concentrations of approximately 7 ppm for a continuously purged system so this method would not have an acceptable detection limit if a continuous flow system was utilized to prepare a head space sample. It should be noted that the primary benefit of the continuous method is that the gas analysis is online; therefore the Hanford 222-S Laboratory technique would likely not be used if the 222-S Laboratory method is chosen.

\section{Review of methods to generate, collect, and analyze gas sample}

As noted above, two distinct tasks must be performed to determine HGR from a sample. These tasks are to generate and collect a gas sample and the subsequent analysis. The following sections discuss these tasks.

\subsection{Generation and Collection of Gas Samples}

The first step, generation and collection of a gas sample, is the more complex task. Whether the sample generated is a head space sample taken from the vessel at the conclusion of the test or a gas flow passed through an on-line analytical instrument, the apparatus generating the gas sample must be carefully 
designed to ensure that the hydrogen concentration measured is representative of the hydrogen generation from the waste sample. The methods and apparatus used have not been standardized across the complex, but PNNL has developed an apparatus that has been used for a number of studies.

The methods to generate the gas sample can be categorized using two salient characteristics: mixing method and operation mode. Mixing during the testing can be continuous, intermittent or not included. Mixing impacts the measured hydrogen generation since the hydrogen generated can be retained in the waste being studied as entrained bubbles. The mode of operation can either be a batch process in a sealed vessel or a continuous flow process in an "open" system. The PNNL method [Bryan, 2004] is an unmixed, sealed vessel process utilizing a small amount of sample while other laboratories have used similar methods as well as continuous flow, mixed systems [Pareizs, 2006].

A key requirement of any method to generate a representative gas sample is to ensure that all hydrogen generated by the waste is collected. The vessel should be checked prior to starting the test to ensure that the system is leak-tight. For the continuous flow, open system leaks from the system do not impact the accuracy of the test provided that the 1) total air purge is known 2) the leak isn't on the purge line to the vessel and 3) that the gas analyzed by the analyzer passed though the vessel (ie. the leak isn't allowing room air to be sampled). SRNL testing has typically added as tracer gas (such as helium) to the air purge to ensure that the gas analyzed is not room air. SRNL typically ensures the a seal by performing a comparison of purge flow to vent flow. A flow controller is used to introduce a known purge into the vessel and a flow meter on the vent line measures the gas flow out of the vessel. When the vent flow is within $90 \%$ of the purge flow, the vessel is considered leak tight. This leak check is not as rigorous as the checks required for sealed systems because the method is less sensitive to leaks.

Ensuring that a sealed system is leak tight would involve pressurizing the vessel to a set pressure and measuring the pressure decay curve. A leak rate can then be calculated from the pressure decay curve using the Ideal Gas Law. Leak rates less than $5 \%$ of the expected hydrogen generation rate are needed to allow measurement of $95 \%$ of the hydrogen generated. For hydrogen generation at the LAW action limit, the allowable leak rate would be $1.85 \mathrm{E}-09$ gmol- $\mathrm{H}_{2} / \mathrm{hr}$ (it is assumed that the leak rate of other gases would be lower). In order to measure hydrogen in systems with lower generation rates, the allowable leak rate is reduced linearly with the desired detection limit. During sealed tests, pressure in the vessel will increase as gases are generated. Monitoring the system pressure in a sealed test is necessary to verify no leaks form during the test and to allow gas generation rate as a function of time to be measured.

Another consideration during the testing is whether the vessel is inerted or if the cover gas is simply air. Inerting the vessel has typically been performed during PNNL measurements of HGR [Bryan, 2004]. The presence of molecular oxygen was noted to enhance hydrogen generation for selected species [Bryan, 2004]. Therefore, air or a neon-oxygen mixture is recommended as the cover gas during testing. However, an inert gas purge may be required to achieve the detection limit requirement for staged LAW feed samples during continuous testing as an inert cover gas allows a greater sensitivity for hydrogen and other gas species during analysis. Hydrogen in atmospheric air is typically $0.5 \mathrm{ppm}$ and could be higher inside buildings, therefore use of instrument air systems for the air purge is not recommended unless the hydrogen concentration is measured. Purified bottled air supplies would eliminate the background hydrogen if elevated hydrogen was noted in the instrument air. 


\subsubsection{Mixing}

It has been shown that static waste sludges and solutions can retain hydrogen through adsorption and bubble entrapment [Bibler, 1992 and Pareizs, 2006]. The retained hydrogen is typically released when the materials are mixed. This retention and subsequent release is the focus of calculation and HGR modeling of design basis accident for the WTP facility involving hydrogen accumulation [Meacham, 2009]. As stated above in Section 5.1, a key feature of the apparatus will be to ensure that any hydrogen evolved is measured during the test. Mixing is considered a key component of the test apparatus to ensure hydrogen is not retained in the sample and to obtain a conservative HGR measurement.

The retention of hydrogen in waste slurry during studies with SRS waste is illustrated in Figure 1 [Bibler, 2007]. Evolved hydrogen was not detectable during this study with $110 \mathrm{ml}$ of material until 5 hours into the test as the majority of hydrogen generated during this time was accumulated in the slu dge material. Steady state evolution was not noted until 50 hours into the test. In addition, the steady state evolved rate during static conditions was slightly below the rates noted during agitation. When agitation was stopped, the evolved hydrogen again went to zero while hydrogen acc umulated in the sludge (not shown in Figure $1)$.

These results were obtained for DWPF process slurries which are more viscous and contain higher solids content than the feed to the WTP pretreatment plant. However, the DWPF slurries tested were less viscous than the process slurries expected after the cross-filtration and washing steps [Pareizs, 2006 and Poloski et al, 2006]. It is expected that the more viscous materials will retain more hydrogen than the less viscous materials, therefore the ability of the apparatus to detect hydrogen retention in DWPF process slurries indicates an ability to detect hydrogen retention in WTP process slurries as well as pointing to the need for mixing during the study.

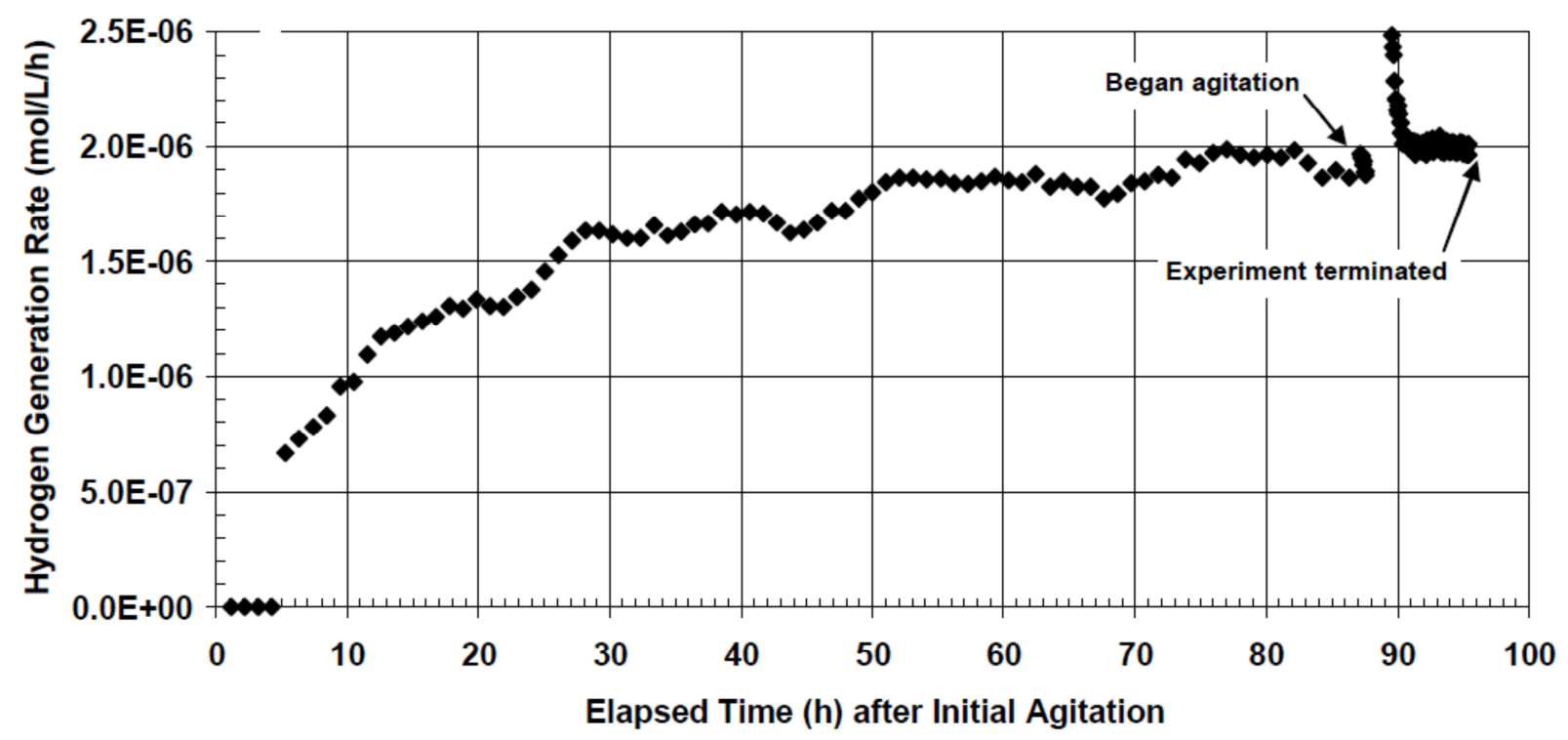

Figure 1. HGR during Static Testing of SRS HLW Sludge 
While select wastes may have low retention, the HGR apparatus will be utilized to measure the HGR for a wide range of materials. It is known that some wastes at the Hanford site retain significant amounts of evolved gases [Meacham, 2009]; therefore the HGR apparatus should have provisions to mix the sample during the measurements. Mixing intermittently during testing in sealed vessels (or just prior to headspace sample collection) would likely be adequate as the goal is simply to ensure that any evolved gases are not retained by the slurry when taking the headspace sample. Determination of operating parameters will be addressed during method development.

\subsubsection{Mode of Operation}

The majority of HGR measurements to date have utilized a static method where sealed containers are used to accumulate evolved gases for a specified period of time, after which the vapor space is sampled to determine hydrogen concentration. Continuous methods have been used during DWPF qualification that use a continuously purged vessel connected to an online gas chromatograph to measure hydrogen generation in real time. This system is described in detail below.

\subsubsection{Continuous methods}

A continuous method for determination of HGR would involve an agitated vessel with purge, system vent gas system, and an online gas analyzer. The sample to be tested would be added to the vessel and the system sealed. A leak check would be performed, and then the purge and mixing started. The simple vent gas system would likely consist of a reflux condenser to prevent water loss and a filter to prevent particulate entrainment. The gas analyzer would likely be located in a hood adjacent to the hot cell. The response time of the system would depend on the head space volume and purge rate.

The advantages of a continuous system are significant and include:

- Stirred and unstirred test samples

- Easier pressure protection because vessel is not sealed

- Steady state rates measured directly by online instrumentation

- Results are obtained in real time

- Head space samples can still be taken for offline analysis

- Less impacts by small leaks or hydrogen permeation through septa

- System volume and pressure measurements not needed

- Consumption of oxygen would not lead to depletion since a continuous supply is provided

One disadvantage of the continuous system is that the hydrogen is not allowed to accumulate; therefore the concentration of hydrogen in the vent gas may be below the detection limits for the analyzer. However, this disadvantage can be mitigated through adjusting the apparatus purge rate and sample size. Please see Section 7.7 below .

Continuously purged vessels were used to measure static and mixed hydrogen generation rates from DWPF process slurries prepared in the Shielded Cells as shown in Figure 2 [Bibler, 2007 and Pariezs, 2006]. Tests were performed with sample volumes of approximately 240 and $110 \mathrm{ml}$ per test with purge rates of $10 \mathrm{ml} / \mathrm{min}$. Steady state measured HGR from tests varied from 5.8E-06 gmol/L-hr to 8.3E-06 gmol/L-hr and hydrogen was detectable at approximately 7E-07 gmol/L-hr. The HGR at the HLW action 
limit (2.1E-06 gmol/L-hr) for WTP is within the method detection limits. While these tests indicate the practicality of the continuous method for measurement of the HGR for the HLW, the action limit for LAW (3.7E-07 gmol/L-hr) is approximately $1 / 10^{\text {th }}$ the limit for HLW. Hence, the error associated with HGR results for LAW samples may be higher due to measurement sensitivity or detection limits, and may require a larger sample volume or lower purge rate.

The above tests have shown the practicality of using a continuous system to measure the amount of hydrogen retention in HLW slurries. However, it is difficult to separate the impact of settled solids from the hydrogen retained in the bulk fluid, although the solubility of hydrogen in the bulk fluid is generally very low. Measurement of hydrogen retention in a solids bed with radioactive samples using sealed vessels was not found in the literature, although a current test program at SRNL is attempting to fabricate a sealed apparatus for precisely this purpose [Scogin, 2011]. The difficulties in performing the test in a sealed system are significant as it is difficult to determine whether or not hydrogen measured was retained in the solids at any time during the test. Although the method is capable of measuring hydrogen retention in the sample if the hydrogen generation in the sample is high enough to be detected, no attempt was made to scale the results obtained from the study illustrated in Figure 1, with the authors stating, "It is not possible to quantitatively extrapolate these retention fractions to large tanks." No methods were identified in the literature to support a scaling method for the results from the retention data; however tests with kaolin and lake sediments suggest that the lab-scale test will result in a very conservative and bounding estimate for retained gases [Gauglitz, 2012]. If the test protocol incorporates mixing into the apparatus, then the test results will not be impacted by hydrogen retention in a settled solids bed. 


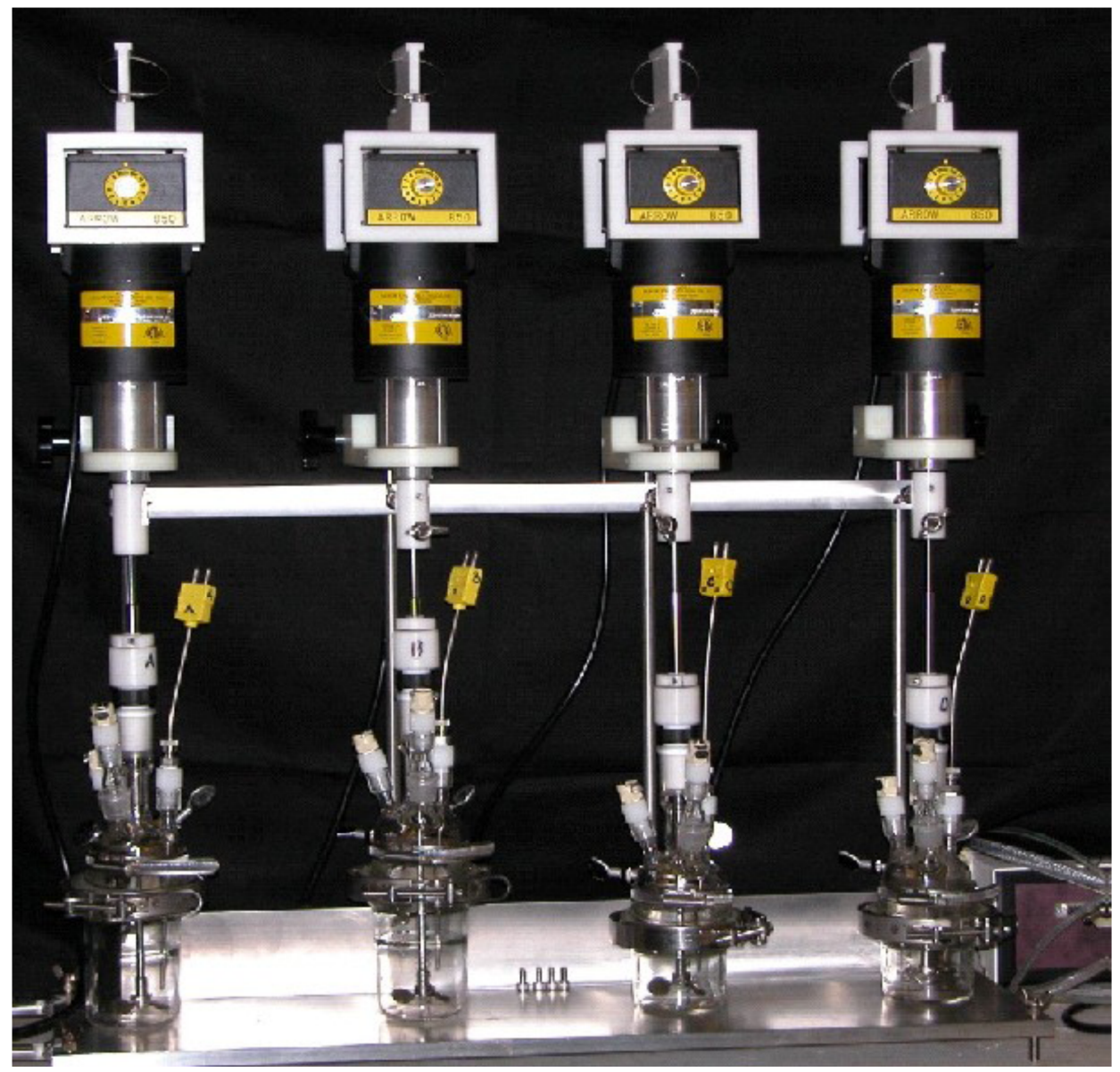

Figure 2. Continuously Purged HGR Apparatus used during DWPF Process Slurry Testing (pictured during water testing)

As shown in Figure 1 above, hydrogen was not detectable until the evolved HGR reached approximately 7E-07 gmol/L-hr. Decreasing the purge rate from the $10 \mathrm{ml} / \mathrm{min}$ used during the study would lower the detectable HGR to below the required value to detect HGR at the LAW action limit. The expected hydrogen gas concentration at the LAW action limit is approximately $7 \mathrm{ppm}$ if the vessel purge is 2 $\mathrm{ml} / \mathrm{min}$ while the minimum detection limit during the study was $1 \mathrm{ppm}$. It should be noted that lowered air purge rates increase the time required for gases evolved to reach the analytical instruments, therefore line sizes should be kept as small in diameter as practical.

Increasing the sample size could also be utilized to increase the hydrogen concentration at a specified purge rate, but the amount of sample required for the WTP waste qualification program is likely to be larger than desired and efforts are underway to minimize the amounts of sample needed.

An example of a continuously purged and agitated apparatus is shown in Figure 3. Temperature control is shown using recirculated water, but a thermostatically controlled heating mantle could be used instead. 
SRNL-STI-2012-00511

Revision 0

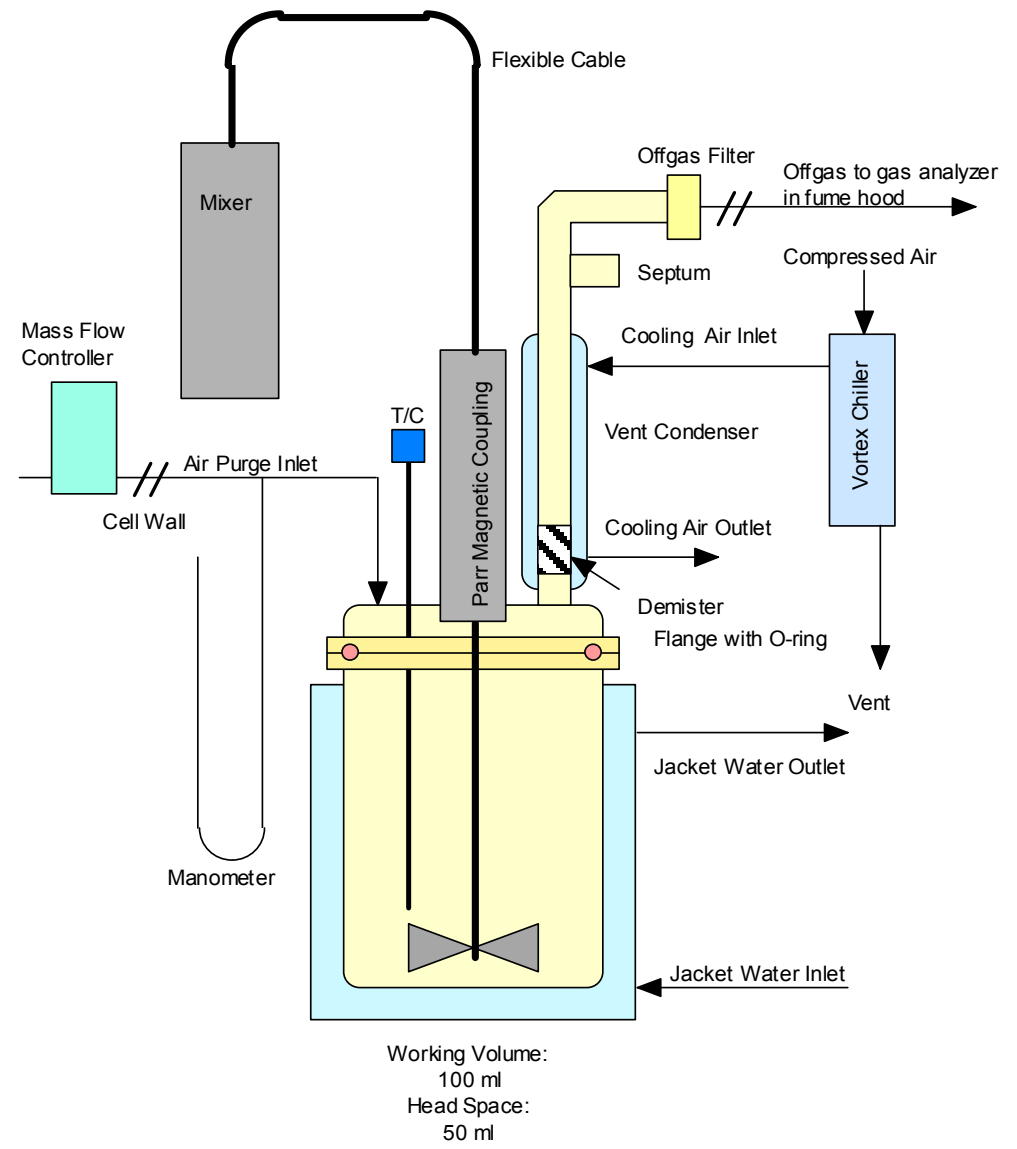

Figure 3. Continuously Purged and Agitated Apparatus for HGR Measurements

\subsubsection{Sealed Vessel Methods}

As stated above, the majority of HGR measurements performed throughout the DOE complex have used sealed systems that allow hydrogen to accumulate in a sealed vessel [Bryan, 2004, Person 1996]. At the end of the specified time, a head space sample is pulled and analyzed by laboratory gas analyzers. Typically, agitation has not been incorporated into these systems. Precise system volume and pressure measurements during the tests are required to determine gas volumes evolved during the tests Errors in system volume and pressure measurements will be directly proportional to the accuracy of the method (a $5 \%$ error will result in 5\% uncertainty) Therefore, these parameters must be measured precisely enough to allow the desired measurement uncertainty to be achieved. In addition, the pressure measurement must be sufficiently accurate to allow a leak check to be performed with sufficient accuracy to achieve the method detection limit desired.

Head space volume is typically determined by injecting a known sample volume (or opening the system to a known volume under vacuum) and measuring the pressure response. System volume is then calculated from the Ideal Gas Law. The sealed system must be completely gas-tight during the test or accumulated hydrogen will be lost during the test. A leak test is performed after the sample is loaded and 
sealed in the test vessel, typically by pressurizing the system and measuring pressure drop after several hours at pressure. The system is then purged to remove any hydrogen, typically with an inert gas. The vessel is then sealed and hydrogen is allowed to accumulate. Vessel pressure is typically measured continuously during the accumulation period to monitor the vessel seal. Pressure is expected to steadily increase during the test; a drop in pressure can indicate seal failure.

At the end of the accumulation period, a gas sample is taken by opening the system to an evacuated bottle. The sample bottle is typically 4 to 10 times the volume of the sample vessel to ensure that the majority of the gas in the sample vessel is captured in the sample. The vacuum may release any trapped gas in the slurry or solution, but the effectiveness of this method of removing entrained gasses compared to mixing the sample could not be determined. The bottle is transported to an analytical laboratory and the hydrogen concentration is measured. Ideal Gas Law calculations, system pressure, and head space volumes are used to convert the measured concentration into a hydrogen generation rate during the test. Agitation during the test has typically not been incorporated into the test apparatus.

The sample size needed to perform a sealed vessel test can be smaller than needed for the continuously purged system. As shown in Figure 4, the apparatus used to perform HGR measurements for a number of the PNNL studies utilizes approximately 15 to $30 \mathrm{ml}$ of sample as the vessel shown is $\sim 30$ to $60 \mathrm{ml}$ in total volume ( $\sim 1.75 \mathrm{~cm}$ diameter and 14 to $27 \mathrm{~cm}$ high). The 304L SS vessel is wrapped in heating tape and insulated. Two thermocouples are attached to the external body, one for temperature control and one for over-temperature protection. Two thermocouples are inserted through the cap. The thermocouple centered in the lower half of the vessel monitors the temperature of the liquid phase; the one centered in the upper half monitors the gas phase temperature within the reaction vessel. The reaction vessels are connected by a thin $(0.0058-\mathrm{cm}$ inside diameter) stainless steel tube to a gas manifold outside the hot cell. A stainless steel filter $(60-\mu \mathrm{m}$ pore size, Nupro) protects the tubing and manifold from particulate contamination. A thermocouple is attached to this filter as well.

Mixing is not incorporated in this apparatus; therefore hydrogen retained by the sludge is potentially not measured. Test durations ranged from 17 to 300 hours, with a typical duration of close to 50 hours. It should be noted that many of the tank samples were irradiated by adding a cesium capsule to the test to allow the measurement of radiolysis to be measured faster than by self-radiation. Tests with dose rates similar to the dose expected in the tank farm tank were performed over 30-40 days and these tests also included an external radiation source as the self-radiation rate is reduced by the small sample size versus the waste tank conditions [King, 1999]. A comparison of the test duration in the PNNL studies to the time to reach steady state in Figure 1 should not be done as the geometries and volumes of the two systems are very different. The use of an evacuated sample bulb to extract the gas sample is done to ensure that all gases in the chamber are sampled, but the retained hydrogen may not be released by application of vacuum. As shown in Figure 6, the PNNL test system was configured to allow multiple samples to be tested at the same time. 
SRNL-STI-2012-00511

Revision 0
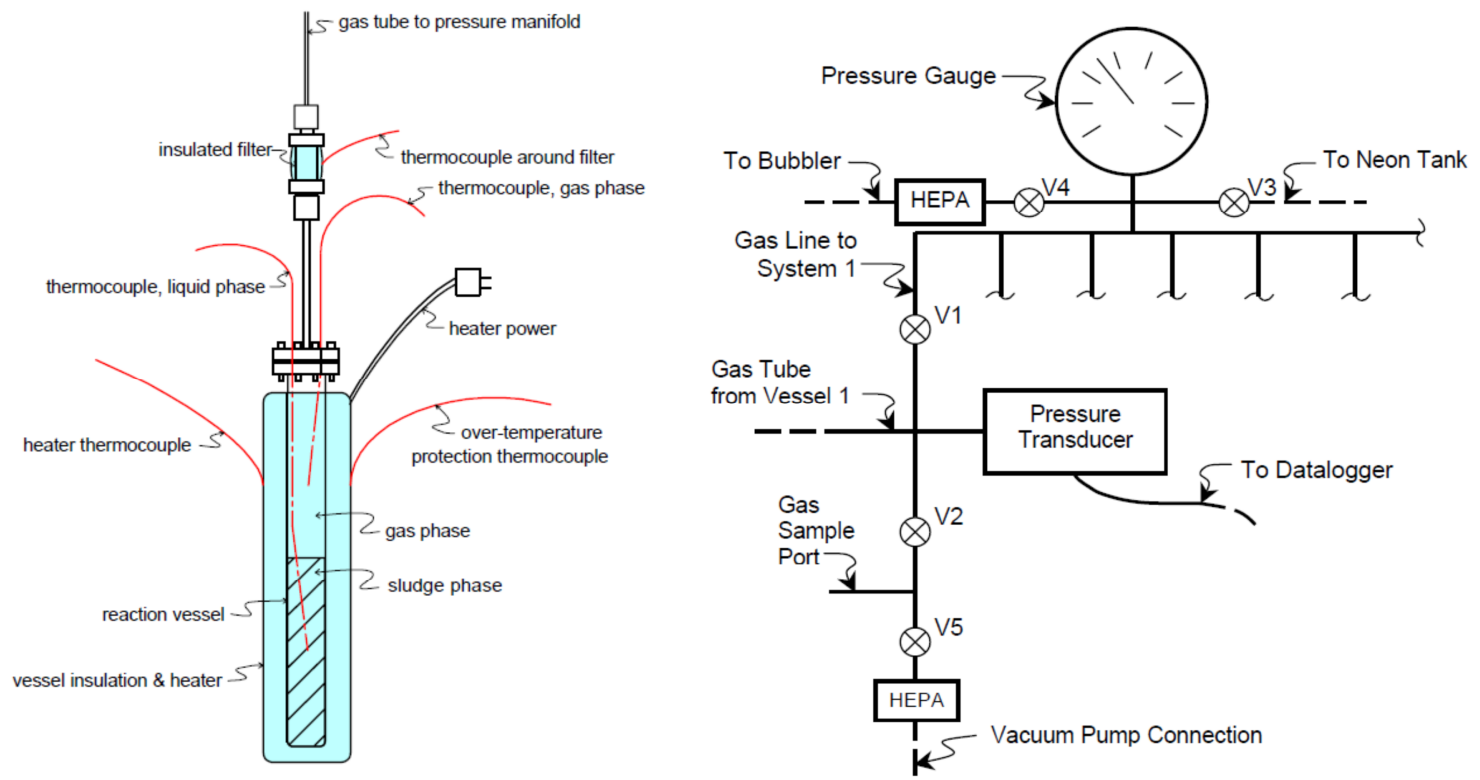

Figure 4. Sealed Vessel Apparatus used by PNNL for HGR Head Space Sample Preparation

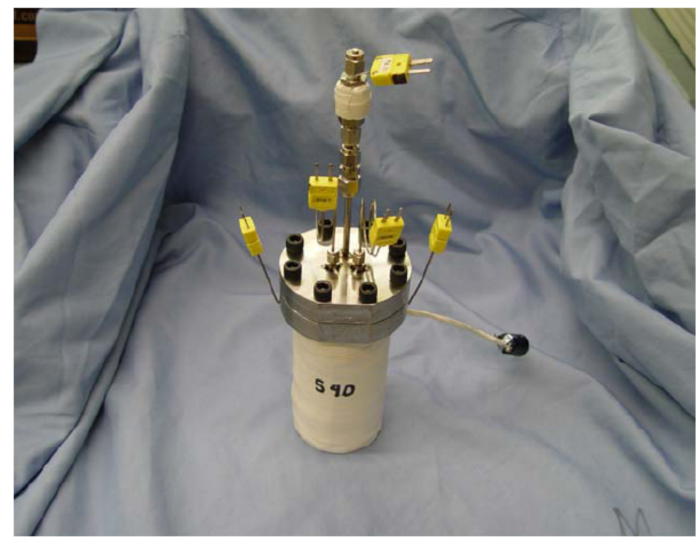

Figure 5. Photograph of Sealed Vessel used during PNNL HGR Measurements 


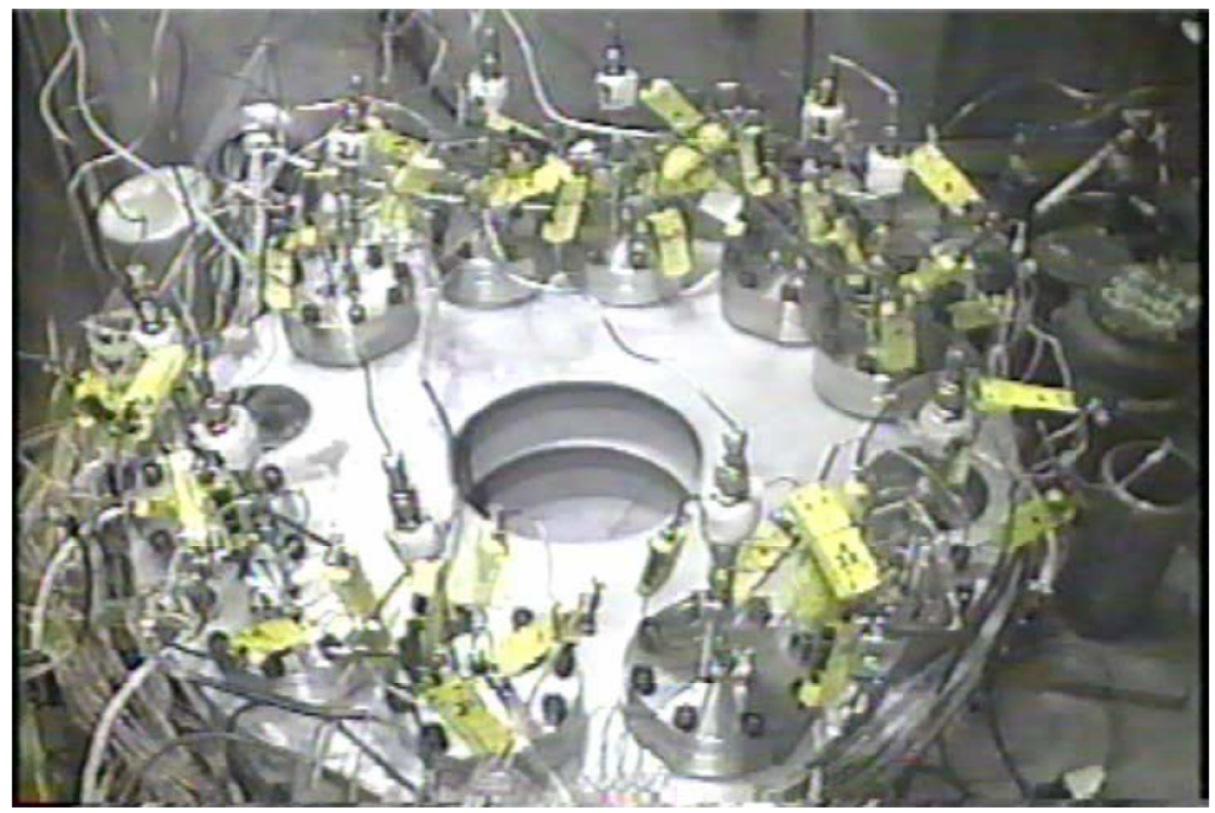

Figure 6. HGR Vessels During Testing

PNNL has used a sealed vessel that incorporates a mixer for testing with simulated waste materials [Bryan, 2004], as shown in Figure 7. Although not shown in the diagrams, pressure was measured during the testing. The method is similar to the static method used during hot cell work without the gas filter. Testing was performed with $75 \mathrm{ml}$ of simulant and shows that a static method that incorporates mixing is a practical alternative to a continuous flow system. The increased volume used during this study versus the sealed static method reflects the need for more volume to allow the stirrer to operate effectively. 
SRNL-STI-2012-00511

Revision 0

(a) Valving for gas inlet and sampling

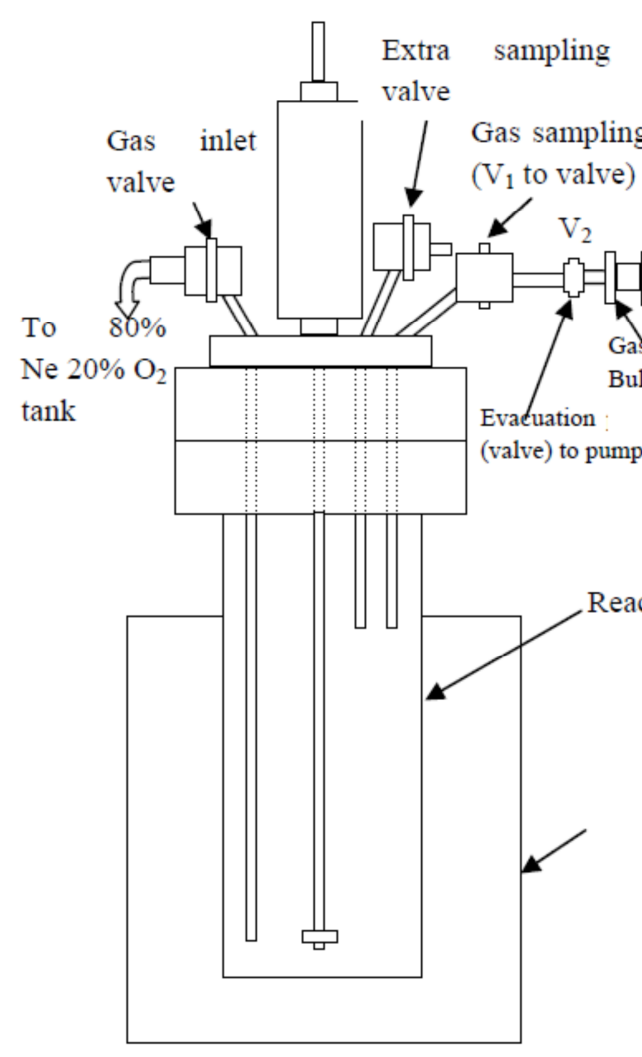

(b) Thermocouples and stirring

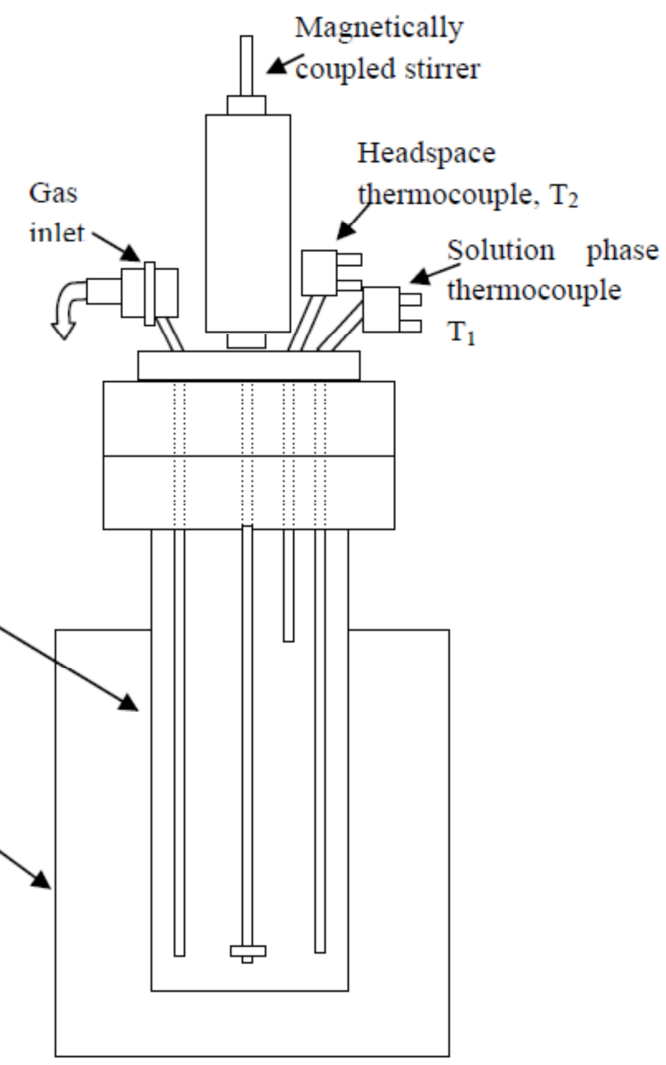

Figure 7. Sealed Vessels used in PNNL Study of Impact of Mixing

\subsection{Review of methods to analyze gas sample}

The measurement of hydrogen concentration in gas can be performed by a variety of different methods, including gas chromatography, mass spectroscopy, as well as direct sensing solid state chips. WTP has considered a method developed by the Hanford 222-S Laboratory, using gas chromatography to measure hydrogen concentrations in head space samples [McCluskey, 2011] as reviewed above in Section 4. This method is adequate unless a lower detection limit is desired to perform analysis of samples taken from a continuous flow system. No additional review of offline instrumentation to measure head space samples was performed since an existing Hanford Site method exists.

A continuous flow system would require online hydrogen gas measurement in order to take full advantage of the benefits of the continuous nature of the method. Online measurements have been performed at SRNL using all three methods listed above (mass spectroscopy, gas chromatography, and solids state chips) to measure hydrogen. Gas Chromatography (GC) has been utilized to measure HGR from HLW slurries using sample sizes comparable to the sample sizes specified for WTP waste qualification. GC instruments are available that measure very low hydrogen concentrations in inert gases and would meet 
the detection limits needed for a continuous flow system at the LAW action limit [Pareizs, 2006]. The testing at SRNL demonstrated a detection limit of approximately $1 \mathrm{ppm}$ for an air purged system using gas chromatography in radioactive environment.

Mass spectroscopy instruments are also available with detection limits that would allow a continuous method to be utilized at the specified sample volume and purge rates. The solid state sensing chips, such as incorporated into the HY-OPTIMA instrument from H2Scan are not sufficiently accurate for use in the continuous flow systems (although these instruments could likely be used for continuous monitoring of a sealed test).

It should be noted that the process samples are expected to have much lower emissions than the action limit. Therefore, the actual hydrogen emissions are likely to be less than detection limits for many LAW samples using a continuous flow system.

\section{Literature Review Summary}

The analytical method specified in the Hanford 222-S Laboratory procedure [McCluskey, 2011] is adequate to perform measurement of head space samples from static tests, but methods to generate the head space sample are not specified. The method detection limit of $25 \mathrm{ppm}$ is not adequate to perform analysis of head space samples from a continuously purged apparatus, but this apparatus is expected to have online gas analysis.

HGR measurements have typically relied on static testing in sealed containers to generate head space samples.

SRNL has performed HGR measurements using continuously purged vessels with online gas analysis for HLW system using similar sample size as expected for the WTP waste qualification.

Accumulation of hydrogen in static slurries can impact the measured HGR, particularly for short duration tests, even if the sample size is small.

Mixing allows measurement of all hydrogen generated from radiolysis by preventing accumulation of gases in the slurry. Using a vacuum sampler with a much larger volume than the sample being measured in lieu of mixing may also remove entrained gasses, but some hydrogen may be retained.

Existing models provide robust and bounding HGR rates. Measurement of the HGR during WTP waste qualification is expected to provide further confirmation of the effectiveness of existing models. Measurement of HGR is not performed during feed qualification for the DWPF at SRS as the HGR models are deemed adequate.

\section{Recommended Method to Measure Hydrogen Generation Rate}


A continuous flow system with online gas analysis is recommended to measure HGR during waste qualification because this mode of real-time measurement offers significant advantages. This technique will require careful selection of the gas instrumentation to ensure that the detection limits and analytical uncertainty are sufficient to perform the measurement. The basis for this recommendation is provided in the sections below.

\subsection{Basis for Recommendation and Discussion}

A comparison of the continuously purged system with sealed systems is shown in Table 1.

Table 1. Comparison of HGR Measurement Methods

\begin{tabular}{|c|c|c|c|}
\hline Criteria & $\begin{array}{l}\text { Continuous } \\
\text { Flow }\end{array}$ & Static / Sealed & Sealed/ Mixed \\
\hline Sample Size & $100 \mathrm{ml}$ & $15 \mathrm{ml}$ & $100 \mathrm{ml}$ \\
\hline Ease of remotability & $\begin{array}{l}\text { Remote } \\
\text { operations } \\
\text { demonstrated }\end{array}$ & $\begin{array}{l}\text { Remote operations } \\
\text { demonstrated }\end{array}$ & $\begin{array}{l}\text { Remote } \\
\text { operations } \\
\text { demonstrated }\end{array}$ \\
\hline Costs to develop method & $\begin{array}{l}\text { Purchase and } \\
\text { maintenance of } \\
\text { analyzer } \\
\text { increases costs }\end{array}$ & & \\
\hline Detection limit & $\begin{array}{l}\begin{array}{l}\text { Dependent on } \\
\text { purge rate and } \\
\text { sample size }\end{array} \\
\text { 5.4E-08 } \\
\text { gmol/L-hr }\end{array}$ & $\begin{array}{l}\text { Dependent on test } \\
\text { duration, sample } \\
\text { size, and head } \\
\text { space volume }\end{array}$ & $\begin{array}{l}\text { Dependent on } \\
\text { test duration, } \\
\text { sample size, } \\
\text { and head space } \\
\text { volume }\end{array}$ \\
\hline TAT & 2 days & 2 days* & 2 days* \\
\hline Data collection & $\begin{array}{l}\text { Temperatures } \\
\text { Mixing Speed } \\
\text { Purge Rate } \\
\text { Gas } \\
\text { composition } \\
\text { System } \\
\text { Pressure }\end{array}$ & $\begin{array}{l}\text { Temperatures } \\
\text { Mixing Speed } \\
\text { System Pressure }\end{array}$ & $\begin{array}{l}\text { Temperatures } \\
\text { Mixing Speed } \\
\text { System } \\
\text { Pressure }\end{array}$ \\
\hline Impact of sealing & $\begin{array}{l}\text { Less } \\
\text { susceptible to } \\
\text { leaks unless on } \\
\text { purge air }\end{array}$ & $\begin{array}{l}\text { Hydrogen } \\
\text { measurement } \\
\text { impacted by all }\end{array}$ & $\begin{array}{l}\text { Hydrogen } \\
\text { measurement } \\
\text { impacted by all }\end{array}$ \\
\hline
\end{tabular}


SRNL-STI-2012-00511

Revision 0

\begin{tabular}{|l|l|l|l|}
\hline & supply & leaks & leaks \\
\hline Settled Solids Bed Impacts? & None & $\begin{array}{l}\text { Settled solids bed } \\
\text { impacts results in } \\
\text { a non-predictable } \\
\text { manner }\end{array}$ & None \\
& & . & \\
\hline
\end{tabular}

*Dependent on detection limit required

\subsection{Scaling}

No issues with scaling of overall hydrogen generation rate results have been identified from the literature review. If needed, the results from the small scale testing can be used as a comparison to results from the HGR models already developed and utilized in the WTP safety analysis. These models can then be used to scale the test results to full scale for use in WTP calculations as needed.

While overall hydrogen generation results are not impacted by scaling issues, one of the subtasks is a determination of the impact of settled solids. Scaling down a test to determine how settled solids impact the hydrogen generation or how much hydrogen is retained by the settled solids is problematic. While Figure 1 above shows that a small sample can be impacted by solids and/or mixing during the test and that the results are measurable, it is not possible to determine how these results scale from the available literature. Based on studies with kaolin, the small scale results are likely bounding [Gauglitz, 2012] while studies at SRS indicate retention could be very high [Ledbetter, 2004]. The scaling of hydrogen retention in settled beds is a knowledge gap for the measurement of HGR.

\subsection{Design / System Configuration}

The apparatus will be similar to the designs used at SRNL to evaluate DWPF process slurries as described in Section 5.1, but will incorporate design features to allow re-use. A simple drawing of the expected apparatus is shown above in Figure 3. The apparatus can be divided into separate systems to include the vessel and lid, mixing system, purge system, temperature control system, and vent gas system. The working volume of the system will be $100 \mathrm{ml}$ with a vapor space volume as small as practical.

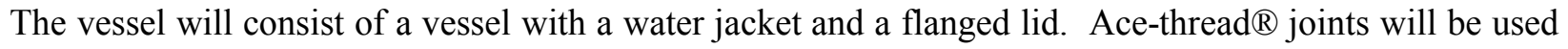
on the lid when practical to connect the purge and vent gas lines, thermocouple, and mixing shaft seal. A fill port will also be incorporated into the vessel lid.

The mixing system will be comprised of an impeller, shaft, shaft seal, coupling, flexible shaft, and mixer motor. The motor will have a digital indicator to allow precise speed control. Agitator speed control allows the mixing from one test to be repeated in other tests. The design of the vessel and mixing system will determine the mixing speed required as well as the amount of tolerance allowed for the mixing speed. The shaft seal will likely be a magnetically coupled seal similar to the Parr A2140HC. 
The purge system will consist of one or two mass flow controllers to provide flow control, air or neonoxygen purge gas, and a manometer for pressure indication. The manometer also provides overpressurization protection for the system.

The temperature control system is expected to be a water bath to provide temperature controlled water to the vessel water jacket. A small Peltier cooled circulator could be configured for remote operation and installed in the cells to avoid running water in and out of the shielded cell. The vent gas system consists of a demister pad to minimize entrainment of the sample into the vent gas system, a condenser to minimize sample water loss, a filter to further mitigate particulate entrainment, a vent line to a fume hood, and an instrument to measure hydrogen concentration in the gas stream. The vent line from the system could be returned to the shielded cell if needed.

\subsection{Operation / Remote Operation}

The remote operation of a continuous flow apparatus has been demonstrated by SRNL, although some modifications will be needed to allow the apparatus to be reusable versus the one-time use typically employed for SRNL hot cell work. The basic operational steps are:

- Replace consumable components (O-rings, gaskets, vent filter, etc.)

- Assemble apparatus and leak test

- Remove lid or open port to allow sample to be added

- Weigh container holding sample

- Add process sample to be tested

- Reweigh container that held sample to determine amount added

- Reassemble vessel/close port and repeat leak test

- Start mixer and adjust speed based on visual observations

- Start cooling flow to vent condenser

- Begin vessel purge flow and gas analysis

- Heat/cool vessel to desired temperature

- Obtain gas composition data after vessel reaches steady-state temperature

- Adjust temperature to next setpoint

- Obtain gas composition data after vessel reaches steady-state temperature

- Stop mixing and allow solids to settle

- Obtain gas composition data during settling and for specified time after settled bed has reach steady-state volume

- Restart mixer and obtain gas composition data during resuspension of settled solids

- Repeat steps if required

- Remove sample

- Disassemble apparatus and rinse

- Clean by soaking in nitric acid bath

- Remove from bath and rinse with DI water

- Allow apparatus to air dry 
Of the steps listed above, the leak check on a continuous flow apparatus is the only step with limited amounts of experiences listed in the literature. The leak test could be performed by installing a pressure gauge on the vessel, plugging the gas line, and performing a pressurized test. However, the continuous flow apparatus does not depend on a leak tight apparatus to obtain the HGR. As long as it can be certain that the entire air purge is reaching the vessel and that the gas sample measured has passed through the vessel then the measurement will be accurate. A tracer gas is often utilized to ensure that the gas being measured is not room air due to a leak in the gas line. SRNL testing utilizes systems where the air purge and tracer gas flow controllers, mixer controller, and recirculator water bath controller are external to the cell. The remaining components would be inside the cell up to and including the filter on the gas line to the analyzer. The gas analyzer is typically contained in a fume hood and the vent lines are routed back into the hot cell. It is expected that the system designed for the HGR measurement would be similar.

\subsection{Data Collection}

The following measurements are needed during the test: Temperature of the process fluid, purge rate of vessel, condenser temperature, mixer speed, vessel pressure, and gas analysis of hydrogen. Measurement of neon, oxygen, nitrogen, carbon dioxide, and nitrous oxide are also desirable. In addition, the ability to measure the vessel weight prior to and after sample addition is required. Time measurement is not required for the continuous flow system.

\subsection{Accuracy of Method}

The accuracy of the continuous method for HGR measurement will depend on a number of measured values. First, the amount of sample added to the vessel is critical to the calculation of HGR on a per kilogram basis from the measured hydrogen emissions. Next, the temperature must be accurately measured since the HGR is known to be dependent on temperature. The amount of purge added must also be measured accurately to allow the measured hydrogen concentration to be converted to an absolute amount of hydrogen emitted. Finally, the hydrogen concentration in the gas stream must be accurately measured along with selected other species to determine in-leakage, gas consumption, and gas generation.

The accuracy of the sample weight will be determined by the accuracy of the scale to a certain extent, but using a scale in a hot cell with large air flows means the accuracy is dependent more on the type of enclosure used, how much vibration is transferred to the scale, etc. In other words, the environmental conditions could limit the accuracy of the scale to $+/-1$ gram. For a $100 \mathrm{ml}$ sample, this value represents less than $1 \%$ uncertainty.

Temperature measurements using thermocouples have been employed in past measurements of HGR. Typically, accuracies with thermocouples of $+/-2$ degrees Celsius are easily achieved. The uncertainty in temperature measurement does not directly translate into uncertainty in the HGR since the temperature dependence is not linear. In addition, the impact of temperature on the hydrogen generation from thermal reactions is the opposite of the impact of hydrogen generation from radiolysis. As the relative contributions from thermal and radiolytic hydrogen will vary by tank, it is not possible to quantitatively determine the amount of uncertainty introduced by the 2 degree Celsius accuracy. It is noted that previous measurements of HGR have utilized thermocoupless for temperature measurement therefore the use of standard thermocouples was deemed adequate. It is noted that a study using simulants estimated at 
$20 \%$ impact on HGR from a 2 degree Celsius difference at 90 degrees Celsius [Bryan, 1994] while a 0.5 degree error in temperature would reduce impacts to $5 \%$.

The purge rate measurement and control is typically performed with mass flow controllers. These instruments are available with ranges of 0 to $5 \mathrm{ml} / \mathrm{min}$ to allow a purge of $2 \mathrm{ml} / \mathrm{min}$ to be performed with a $+/-5 \%$ precision. SRNL testing has used mass flow controllers from MKS, model numbers have varied.

A gas chromatograph was able to detect hydrogen at $1 \mathrm{ppm}$ in hot cell testing with DWPF process slurries. However, this value was below the calibration curve and the accuracy of the measurement was not determined. Other offgas instruments may be more suited to measurement of hydrogen in this range. The detection limits and accuracy of the method will need to be evaluated during the test program. A precision of $+/-30 \%$ was assumed in this evaluation.

The uncertainty associated with the hydrogen concentration measurement will be the dominant source of uncertainty in the measurement method, based on an assumption of 30\% uncertainty in this value. This value should be used as the combined uncertainty in the HGR measurement. This uncertainty is acceptable provided the method detection limit is sufficient to allow measurement of HGR to ascertain that the HGR is below the appropriate action limit.

\subsection{Detection Limits}

The detection limit of the HGR apparatus is a function of the sample size, purge rate, and detection limit of the gas analyzer. The method detection limit is directly proportional to the gas analyzer detection limit and purge rate while it is inversely proportional to sample size. If the sample size is set to $100 \mathrm{ml}$ and the gas analyzer is capable of detection hydrogen concentration of $1 \mathrm{ppm}$, then the HGR apparatus detection limit can be calculated as a function of purge rate as shown in Table 2 .

Table 2. Detection Limits for Continuously Purged System

\begin{tabular}{|c|c|}
\hline Purge Rate & Detection Limit \\
\hline $\mathrm{ml} / \mathrm{min}$ & gmol/L-hr \\
\hline & \\
\hline 1 & $2.7 \mathrm{E}-08$ \\
\hline 2 & $5.4 \mathrm{E}-08$ \\
\hline 3 & $8.0 \mathrm{E}-08$ \\
\hline 5 & $1.3 \mathrm{E}-07$ \\
\hline 10 & $2.7 \mathrm{E}-07$ \\
\hline 20 & $5.4 \mathrm{E}-07$ \\
\hline
\end{tabular}

The HGR action limits for staged HLW and LAW feed samples are 2.1E-06 and 3.7E-7 gmole/L-hr respectively [Olson, 2008] As shown above, the HGR method is capable of detecting hydrogen concentrations below these levels; therefore the HGR method will be able to show that the HGR is below the action limits for the incoming feed. 
For comparison, a similar evaluation was performed for sealed systems. In these systems, the detection limit is a function of sample size, headspace volume, test duration, and the detection limit of the gas analyzer as well as the accuracy of the pressure measurement and permeability of the vessel seals. To determine the minimum test duration required to reach $25 \mathrm{ppm}$ (lowest calibrated value of the 222-S Laboratory procedure), a calculation was performed assuming hydrogen was the only gas emitted and the pressure measurement and permeability did not impact the results. The results indicate that for a $100 \mathrm{ml}$ sample in a vessel with $100 \mathrm{ml}$ of headspace volume that the sample would need to be held in the sealed system for approximately 3.1 hours if hydrogen is evolved at the LAW action limit. If the system was expected to measure hydrogen at 10X less than the detection limit, the time increases to 31 hours. Hold time for the $100 \mathrm{ml}$ sealed system as a function of desired detection limit is shown in Table 3.

Table 3. Time Required for a Sealed Test

\begin{tabular}{|c|c|}
\hline Desired Detection Limit & Time to reach desired concentration \\
\hline gmole/L-hr & hrs \\
\hline $1.00 \mathrm{E}-05$ & 0.1 \\
\hline $1.00 \mathrm{E}-06$ & 1.1 \\
\hline $3.70 \mathrm{E}-07$ & 3.1 \\
\hline $1.00 \mathrm{E}-07$ & 11.4 \\
\hline $3.70 \mathrm{E}-08$ & 31 \\
\hline $1.00 \mathrm{E}-08$ & 114 \\
\hline $1.00 \mathrm{E}-09$ & 1136 \\
\hline
\end{tabular}

During waste qualification unit operations, measurement of HGR is specified after each ultrafiltration and washing operations on both the permeate and HLW slurries. The permeate has an assumed maximum HGR of 2.7E-7 gmole/L-hr while the ultrafiltration feed and pretreatment vessels have maximum HGR's of 4.2E-6 and 1.1E-5 gmole/L-hr, respectively. The HGR apparatus has detection limits below these expected maximums.

\subsection{Knowledge Gaps}

The review did not identify any knowledge gaps for determination of hydrogen generation rate.

\section{References}

Barber, D. B., Carney, K. P., Hart, P. R., Cummings, D. G., Sayer, M. T., Hendrix, D. L., Shirley, K. T., Demirgian, J. C., "The Determination of the Rate of Hydrogen Generation from Transuranic 003 Type Organic Sludge", ANL/NT/CP-102508, February 2001, Argonne National Laboratory - West, Idaho Falls, ID.

Bibler, N. E., "Radiolytic Hydrogen Production from Process Vessels in HB Line - Production Rates Compared to Evolution Rates and Discussion of LASL Reviews" November 1992, WSRC-RP-92-1312. Savannah River Technology Center, Aiken, SC. 
Bibler, N. E., Pareizs, J. M., Fellinger, T.L., Bannochie, C.J., "Measurement and Prediction of Radiolytic Hydrogen Production in Defense Waste Processing Slurries at Savannah River Site" WSRC-STI-200600114, Rev. 1, 2007. Savannah River National Laboratory, Aiken, SC.

Bibler, N.E., Crawford, C.L., Biddle, C.R., "Results of Scoping Studies for Determining Radiolytic Hydrogen Production from Moist CST and CST Slurries", WSRC-RP-98-01143, October 1998, Westinghouse Savannah River Company, Aiken SC.

Bradley, R.F., "Radiolysis of Liquid Waste During Bedrock Storage”, DP-1264, August 1971, Savannah River Laboratory, Aiken SC.

Bryan, S. A, Levitskaia, T. G., McNamara, B. K., Sell, R.L., Stock, L.M., "Thermal Gas Generation from Various Hanford Wastes in Contact with Inert and Oxygen-Containing Cover Gases-Status Report" 24590-101-TSA-W000-0004-159-00001 Rev 00A, December 2003, Batelle - Pacific Northwest Division, Richland WA.

Bryan, S. A., Delegard, C.H., Schmidt, A.J., Sell, R.L., Silvers, K. L., Gano, S.R., Thornton, B.M., “Gas Generation from K East Basin Sludges - Series II Testing”, PNNL-13446, March 2001. Pacific Northwest National Laboratory, Richland WA.

Bryan, S. A., Forbes, S.V., King, C. M., Sell, R.L., Pederson, L.R., "Gas Generation from Tank 241-SY103 Waste” PNL-10978, April 1996. Pacific Northwest National Laboratory, Richland WA.

Bryan, S. A., Pederson, L.R., "Composition, Preparation, and Gas Generation Results from Simulated Wastes of Tank 241-SY-101" PNL-10075, August 1994. Pacific Northwest Laboratory, Richland WA.

Bryan, S. A., Pederson, L.R., "Thermal and Combined Thermal and Radiolytic Reactions Involving Nitrous Oxide, Hydrogen, Nitrogen, and Ammonia in Contact with Tank 241-SY-101 Simulated Waste" PNL-10748, February 1996. Pacific Northwest National Laboratory, Richland WA.

Bryan, S.A., Camiaoni, D.W., Levitskaia, T.G., McNamara, B.K., Sell, R.L., Stock, L.M., "Gas Generation Testing and Support for the Hanford Waste Treatment and Immobilization Plant" WTP-RPT115, June 2004. Battelle - Pacific Northwest Division, Richland WA.

Crawford, C. L., Duffey, C. E., White, T.L., Sherwood, D.J., "Hydrogen Generation Rate Scoping Study of DOW Corning Antifoam Agent" WSRC-TR-2005-00281, September 2005. Savannah River National Laboratory, Aiken, SC.

Crawford, C.L., Bibler, N.E., "Hydrogen Production in Radioactive Solutions in the Defense Waste Processing Facility", WSRC-TR-95-0090, June 1995. Savannah River Technology Center, Aiken, SC.

Crawford, C.L., Bibler, N.E., "Radiolytic Hydrogen Generation in Savannah River Site (SRS) High Level Waste Tanks - Comparison of SRS and Hanford Modeling Predictions" WSRC-TR-2004-00468, August 2004. Savannah River National Laboratory, Aiken, SC. 
Crawford, C.L., Bibler, N.E., Bibler, J.P., "An Investigation of the Radiolytic Stability of a ResorcinolFormaldehyde Ion Exchange Resin”, WSRC-MS-93-550, February 1994, Westinghouse Savannah River Company, Aiken, SC.

Duncan, G.M.,'Partial Response to Condition of Acceptance Item 2.3 on Evaluation of Uncertainty in the WTP Hydrogen Generation Rate Correlation" CCN-142843, December 2009.

Eager, K., "Revised Calculation of Hydrogen Generation Rates and Times to Lower Flammability Limit for WTP”, 24590-WTP-M4C-V11T-00011, May 2010.

Gauglitz, P.A., Buchmiller, W.C., Probert, S.G., Owen, A.t., Brockman, F.J. "Strong-Sludge Gas Retention and Release Mechanisms in Clay Simulants" PNNL-21167, February 2012, Pacific Northwest National Laboratory, Richland, WA.

Hu, T.A., "Steady-State Flammable Gas Release Rate Calculation and Lower Flammability Level Evaluation for Hanford Tank Waste", RPP-5926, Rev 6., October 2006. CH2M Hill Hanford Group Inc, Richland WA.

Hu, T.A., "Empirical Rate Equation Model and Rate Calculations of Hydrogen Generation for Hanford Tank Waste", HNF-3851, Revision 1., September, 2004. CH2M Hill Hanford Group Inc, Richland WA.

Huckaby, J. L., Mahoney, L. A., Droppo, J. G., Meacham, J. E., “ Overview of Hanford Site High-Level Waste Tank Gas and Vapor Dynamics", PNNL-14831, August 2004. Pacific Northwest National Laboratory, Richland WA.

Jonah, C.D., Meisel, D., Sauer Jr., M.C., "The Radiolytic and Radiolytically Induced Gas Generation in Hanford Waste Tanks", ANL/CHM/PP--77923, Argonne National Laboratory, Argonne, Illinois.

King, C. M., Bryan, S. A., "Thermal and Radiolytic Gas Tests on Material from Tanks 241-U-103, 241AW-101, 241-S-106, and 241-S-102 Status Report", PNNL-12181, June 1999. Pacific Northwest National Laboratory, Richland WA.

King, C. M., Bryan, S. A., Pederson, L.R., "Thermal and Radiolytic Gas Generation from Tank 241-S102 Waste”, PNNL-11600, July 1997. Pacific Northwest National Laboratory, Richland WA.

Ledbetter, L.A., "Hydrogen Retention Rates in Slurried Sludge", WSRC-TR-2004-00077, February 2004, Westinghouse Savannah River Company, Aiken SC.

McCluskey, J. M., "222-S Laboratory Tracer Gas Analysis for Helium, Hydrogen, and Methane using Gas Chromatography/Thermal Conductivity Detector (GC/TCD)”, ATS-LT-523-163, May 2011.

McDuffie, N.G., "Flammable Gas Generation, Retention, and Release in High-Level Waste Tanks Physical and Chemical Models", WHC-SA-2129-FP, March 1994. Westinghouse Hanford Company, Richland, WA.

Meacham, J.E., "Steady-State Flammable Gas Release Rate Calculation and Lower Flammability Level Evaluation for Hanford Tank Waste", RPP-5926, Rev 9. , October 2009. CH2M Hill Hanford Group Inc, Richland WA. 
SRNL-STI-2012-00511

Revision 0

Meehan, J.L., "M-3 Gas Release in Newtonian Pulse Jet Mixer (PJM) Mixed Vessels", 24590-WTP-RPTPET-10-007, February 2010, River Protection Project, Richland WA.

Meisel, D., Jonah, C.D., Kapoor, S., Mathson, M.S., Sauer Jr., M.C., "Radiolytic and Radiolytically Induced Generation of Gases from Synthetic Wastes", ANL-93/43, October 1993, Argonne National Laboratory, Argonne, Illinois.

Meisel, D., Sauer Jr., M.C., Jonah, C.D., Diamond, H., Mathson, M.S., Barnabas, F., Cerny, E., Cheng, Y., "Radiolytic and Radiolytically Induced Generation of Gases in Simulated Waste Solutions", ANL/CCP/PP--74531, February 1992, Argonne National Laboratory, Argonne, Illinois.

Mincher, B., "CSSX Radiolytic H2 Generation ("Thermolysis") Final Report", INL/EXT-09-153402, January 2009, Idaho National Laboratory, Idaho Falls, ID.

Olson, J.W., "ICD-19 - Interface Control Document for Waste Feed", 24590-WTP-ICD-MG-01-019, Rev.5, April 2008, River Protection Project, Richland WA.

Pareizs, J. M., Bibler, N. E., Fellinger, T.L., "Radiolytic Hydrogen Generation and Retention in Tank 40 (Sludge Batch 3) Sludge" WSRC-TR-2005-00555, January 2006. Savannah River National Laboratory, Aiken, SC.

Pederson, L. R., Bryan, S. A., "Status and Integration of Studies of Gas Generation in Hanford Wastes", PNNL-11297, October 1996. Pacific Northwest National Laboratory, Richland WA.

Pederson, L. R., Strachan, D. M., "Status and Integration of the Gas Generation Studies Performed for the Hydrogen Safety Program - FY 1992 Annual Report”, PNL—8523, February 1993. Pacific Northwest Laboratory, Richland WA.

Person, J.C., "Effects of Oxygen Cover Gas and NaOH Dilution on Gas Generation from Tank 241-SY101 Waste”, WHC-SD-WM-DTR-043, May 1996, Westinghouse Hanford Company, Richland WA.

Peterson, R.A., Swingle, R.F., "Hydrogen Retention and Release Summary from Tank 48H from September 1995 to October 1996" WSRC-TR-97-0043, February 1997. Savannah River Technology Center, Aiken, SC.

Peurrung, L.M., Mahoney, L.A., Stewart, C.W., Gauglitz, P.A., Pederson, L.R., Bryan, S.A., Shepard, C.L., "Flammable Gas Issues in Double-Contained Receiver Tanks", PNNL-11836, Rev. 2, August 1998, Pacific Northwest National Laboratory, Richland, WA.

Poloski, A.P, Arm, S.R., Bredt, O.P, Calloway, T.B., Onishi, Y, Peterson, R.A., Smith, G.L., Smith, H.D.,"Final Report: Technical Basis for HLW Vitrification Stream Physical and Rheological Property Bounding Conditions", WTP-RPT-112, Rev 0., January 2006. Pacific Northwest National Laboratory, Richland WA.

Scogin, J. H., Crapse, K. P., "Task Technical and Quality Assurance Plan for Gas Generation, Retention, and Release Study", SRNL-RP-2011-01369, August 2011, Savannah River Technology Center, Aiken, SC. 
Sherwood, D.J. and Stock, L.M.,"Modifying the Hu Correlation to Predict Hydrogen Formation in the Hanford Waste Treatment Plant and Immobilization Plant" 24590-WTP-RPT-RT-04-0002, October 2004, Richland, WA.

Sinkov, S.I., Delegard, C.H., Schmidt, A.J., "Mitigation of Hydrogen Gas Generation from the Reaction of Water with Uranium Metal in K Basin Sludge", PNNL-19135, January 2010. Pacific Northwest National Laboratory, Richland WA.

Stock, L. M., "The Chemistry of Flammable Gas Generation", RPP-6664, October 2000, CH2M Hill Hanford Group, Richland, WA.

Walker, D.D., Crawford, C.L, Bibler, N.E., " Radiolytic Bubble Formation and Level Changes in Simulated High-Level Waste Salts and Sludges - Application to Savannah River Site and Hanford Storage Tanks", WSRC-MS-93-535, February 1994, Westinghouse Savannah River Company, Aiken, SC. 


\section{Appendix A: Documents Included in the Literature Review}

\begin{tabular}{|c|c|c|c|c|}
\hline $\begin{array}{c}\text { Item } \\
\text { Number }\end{array}$ & Documents Included in Literature Review & Comments & $\begin{array}{c}\text { Applicable to } \\
\text { Sealed Vessel } \\
\text { Method }\end{array}$ & $\begin{array}{l}\text { Applicable to } \\
\text { Continuous } \\
\text { Method }\end{array}$ \\
\hline 1. & $\begin{array}{l}\text { Barber, D. B., Carney, K. P., Hart, P. R., Cummings, D. G., } \\
\text { Sayer, M. T., Hendrix, D. L., Shirley, K. T., Demirgian, J. } \\
\text { C., "The Determination of the Rate of Hydrogen Generation } \\
\text { from Transuranic } 003 \text { Type Organic Sludge", ANL/NT/CP- } \\
\text { 102508, February 2001, Argonne National Laboratory - } \\
\text { West, Idaho Falls, ID. }\end{array}$ & $\begin{array}{l}\text { This document describes the } \\
\text { sealed, static test used by } \\
\text { Argonne National Laboratory to } \\
\text { measure radiolytic hydrogen } \\
\text { from organic radioactive wastes. } \\
\text { The methods used were similar } \\
\text { to the PNNL methods except for } \\
\text { sample and vessel volumes. }\end{array}$ & $\mathrm{X}$ & \\
\hline 2. & $\begin{array}{l}\text { Bibler, N. E., "Radiolytic Hydrogen Production from } \\
\text { Process Vessels in HB Line - Production Rates Compared to } \\
\text { Evolution Rates and Discussion of LASL Reviews" } \\
\text { November 1992, WSRC-RP-92-1312. Savannah River } \\
\text { Technology Center, Aiken, SC. }\end{array}$ & $\begin{array}{l}\text { This document describes the } \\
\text { impact of mixing on } \\
\text { measurement of hydrogen } \\
\text { generation from radiolysis. }\end{array}$ & & $\mathrm{X}$ \\
\hline 3. & $\begin{array}{l}\text { Bibler, N. E., Pareizs, J. M., Fellinger, T.L., Bannochie, C.J., } \\
\text { "Measurement and Prediction of Radiolytic Hydrogen } \\
\text { Production in Defense Waste Processing Slurries at } \\
\text { Savannah River Site" WSRC-STI-2006-00114, Rev. 1, } \\
\text { 2007. Savannah River National Laboratory, Aiken, SC. }\end{array}$ & $\begin{array}{l}\text { This document describes the } \\
\text { methods and results from } \\
\text { continuously purged mixed and } \\
\text { unmixed vessels to measure the } \\
\text { HGR from samples of high level } \\
\text { waste during vitrification } \\
\text { pretreatment processing. }\end{array}$ & & $\mathrm{X}$ \\
\hline
\end{tabular}




\begin{tabular}{|c|c|c|c|c|}
\hline $\begin{array}{c}\text { Item } \\
\text { Number }\end{array}$ & Documents Included in Literature Review & Comments & $\begin{array}{l}\text { Applicable to } \\
\text { Sealed Vessel } \\
\text { Method }\end{array}$ & $\begin{array}{l}\text { Applicable to } \\
\text { Continuous } \\
\text { Method }\end{array}$ \\
\hline 4. & $\begin{array}{l}\text { Bryan, S. A, Levitskaia, T. G., McNamara, B. K., Sell, R.L., } \\
\text { Stock, L.M., "Thermal Gas Generation from Various } \\
\text { Hanford Wastes in Contact with Inert and Oxygen- } \\
\text { Containing Cover Gases-Status Report" 24590-101-TSA- } \\
\text { W000-0004-159-00001 Rev 00A, December 2003, Batelle- } \\
\text { Pacific Northwest Division, Richland WA. }\end{array}$ & $\begin{array}{l}\text { This document, along with } \\
\text { others, describes the static } \\
\text { methods used at PNNL to } \\
\text { measure the HGR from Hanford } \\
\text { tank waste samples. This } \\
\text { document discusses the impact } \\
\text { of oxygen in the cover gas versus } \\
\text { the typical inert atmosphere } \\
\text { typically used in PNNL testing. }\end{array}$ & $\mathrm{X}$ & \\
\hline 5. & $\begin{array}{l}\text { Bryan, S. A., Delegard, C.H., Schmidt, A.J., Sell, R.L., } \\
\text { Silvers, K. L., Gano, S.R., Thornton, B.M., "Gas Generation } \\
\text { from K East Basin Sludges - Series II Testing”, PNNL- } \\
\text { 13446, March 2001. Pacific Northwest National Laboratory, } \\
\text { Richland WA. }\end{array}$ & $\begin{array}{l}\text { This document, along with } \\
\text { others, describes the static } \\
\text { methods used at PNNL to } \\
\text { measure the HGR from Hanford } \\
\text { tank waste samples. The } \\
\text { illustrations of the PNNL method } \\
\text { were taken from this report. }\end{array}$ & $\mathrm{X}$ & \\
\hline 6. & $\begin{array}{l}\text { Bryan, S. A., Forbes, S.V., King, C. M., Sell, R.L., } \\
\text { Pederson, L.R., ”Gas Generation from Tank 241-SY-103 } \\
\text { Waste” PNL-10978, April 1996. Pacific Northwest National } \\
\text { Laboratory, Richland WA. }\end{array}$ & $\begin{array}{l}\text { This document, along with } \\
\text { others, describes the static } \\
\text { methods used at PNNL to } \\
\text { measure the HGR from Hanford } \\
\text { tank waste samples. }\end{array}$ & $\mathrm{X}$ & \\
\hline 7. & $\begin{array}{l}\text { Bryan, S. A., Pederson, L.R., "Composition, Preparation, } \\
\text { and Gas Generation Results from Simulated Wastes of Tank } \\
\text { 241-SY-101” PNL-10075, August 1994. Pacific Northwest }\end{array}$ & $\begin{array}{l}\text { This document, along with } \\
\text { others, describes the static } \\
\text { methods used at PNNL to } \\
\text { measure the HGR from Hanford }\end{array}$ & $\mathrm{X}$ & \\
\hline
\end{tabular}




\begin{tabular}{|c|c|c|c|c|}
\hline $\begin{array}{c}\text { Item } \\
\text { Number }\end{array}$ & Documents Included in Literature Review & Comments & $\begin{array}{c}\text { Applicable to } \\
\text { Sealed Vessel } \\
\text { Method }\end{array}$ & $\begin{array}{c}\text { Applicable to } \\
\text { Continuous } \\
\text { Method }\end{array}$ \\
\hline & Laboratory, Richland WA. & $\begin{array}{l}\text { tank waste samples, although this } \\
\text { study was completed using } \\
\text { simulants. The impact of } \\
\text { temperature on HGR rates was } \\
\text { discussed in this study. }\end{array}$ & & \\
\hline 8. & $\begin{array}{l}\text { Bryan, S. A., Pederson, L.R., ’Thermal and Combined } \\
\text { Thermal and Radiolytic Reactions Involving Nitrous Oxide, } \\
\text { Hydrogen, Nitrogen, and Ammonia in Contact with Tank } \\
\text { 241-SY-101 Simulated Waste” PNL-10748, February } 1996 . \\
\text { Pacific Northwest National Laboratory, Richland WA. }\end{array}$ & $\begin{array}{l}\text { This document, along with } \\
\text { others, describes the static } \\
\text { methods used at PNNL to } \\
\text { measure the HGR from Hanford } \\
\text { tank waste samples. This study } \\
\text { was performed with simulants } \\
\text { and discusses the impact of } \\
\text { temperature on the measured } \\
\text { HGR. }\end{array}$ & $\mathrm{X}$ & \\
\hline 9. & $\begin{array}{l}\text { Bryan, S.A., Camiaoni, D.W., Levitskaia, T.G., McNamara, } \\
\text { B.K., Sell, R.L., Stock, L.M., "Gas Generation Testing and } \\
\text { Support for the Hanford Waste Treatment and } \\
\text { Immobilization Plant" WTP-RPT-115, June 2004. Battelle - } \\
\text { Pacific Northwest Division, Richland WA. }\end{array}$ & $\begin{array}{l}\text { This document, along with } \\
\text { others, describes the static } \\
\text { methods used at PNNL to } \\
\text { measure the HGR from Hanford } \\
\text { tank waste samples. In addition, } \\
\text { this report documents testing } \\
\text { done to support application of } \\
\text { the HGR models to WTP process } \\
\text { streams. }\end{array}$ & $\mathrm{X}$ & \\
\hline 10. & $\begin{array}{l}\text { Crawford, C. L., Duffey, C. E., White, T.L., Sherwood, D.J., } \\
\text { "Hydrogen Generation Rate Scoping Study of DOW }\end{array}$ & $\begin{array}{l}\text { This document discusses the } \\
\text { impact of the WTP antifoam }\end{array}$ & $\mathrm{X}$ & $\mathrm{X}$ \\
\hline
\end{tabular}




\begin{tabular}{|c|c|c|c|c|}
\hline $\begin{array}{c}\text { Item } \\
\text { Number }\end{array}$ & Documents Included in Literature Review & Comments & $\begin{array}{l}\text { Applicable to } \\
\text { Sealed Vessel } \\
\text { Method }\end{array}$ & $\begin{array}{l}\text { Applicable to } \\
\text { Continuous } \\
\text { Method }\end{array}$ \\
\hline & 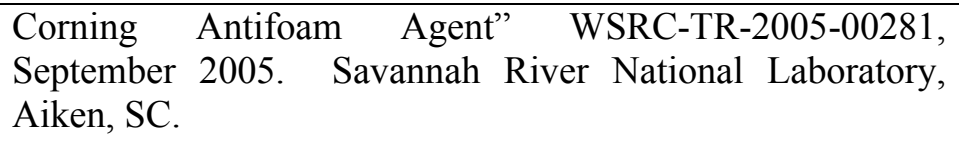 & $\begin{array}{l}\text { agent on hydrogen generation } \\
\text { rates. }\end{array}$ & & \\
\hline 11. & $\begin{array}{l}\text { Crawford, C.L., Bibler, N.E., "Hydrogen Production in } \\
\text { Radioactive Solutions in the Defense Waste Processing } \\
\text { Facility", WSRC-TR-95-0090, June 1995. Savannah River } \\
\text { Technology Center, Aiken, SC. }\end{array}$ & $\begin{array}{l}\text { This document discusses } \\
\text { measurement of HGR from } \\
\text { sealed vessels using simulants at } \\
\text { SRNL. }\end{array}$ & $\bar{X}$ & \\
\hline 12. & $\begin{array}{l}\text { Crawford, C.L., Bibler, N.E., "Radiolytic Hydrogen } \\
\text { Generation in Savannah River Site (SRS) High Level Waste } \\
\text { Tanks - Comparison of SRS and Hanford Modeling } \\
\text { Predictions" WSRC-TR-2004-00468, August 2004. } \\
\text { Savannah River National Laboratory, Aiken, SC. }\end{array}$ & $\begin{array}{l}\text { This document describes the } \\
\text { robustness of the HGR models in } \\
\text { use at Hanford and SRS as well } \\
\text { as how these models compare to } \\
\text { each other. }\end{array}$ & & \\
\hline 13. & $\begin{array}{l}\text { Eager, K., "Revised Calculation of Hydrogen Generation } \\
\text { Rates and Times to Lower Flammability Limit for WTP", } \\
\text { 24590-WTP-M4C-V11T-00011, May } 2010 .\end{array}$ & $\begin{array}{l}\text { This calculation discusses the } \\
\text { impacts of hydrogen generation } \\
\text { on the safety basis of the WTP. } \\
\text { The document addresses the } \\
\text { expected retention of hydrogen } \\
\text { in settled solids in the WTP } \\
\text { vessels as well as using the } \\
\text { existing models of HGR to } \\
\text { determine the allowable } \\
\text { quiescent time for each vessel. }\end{array}$ & $\mathrm{X}$ & $\mathrm{X}$ \\
\hline
\end{tabular}




\begin{tabular}{|c|c|c|c|c|}
\hline $\begin{array}{c}\text { Item } \\
\text { Number }\end{array}$ & Documents Included in Literature Review & Comments & $\begin{array}{l}\text { Applicable to } \\
\text { Sealed Vessel } \\
\text { Method }\end{array}$ & $\begin{array}{l}\text { Applicable to } \\
\text { Continuous } \\
\text { Method }\end{array}$ \\
\hline 14. & $\begin{array}{l}\text { Gauglitz, P.A., Buchmiller, W.C., Probert, S.G., Owen, A.t., } \\
\text { Brockman, F.J. "Strong-Sludge Gas Retention and Release } \\
\text { Mechanisms in Clay Simulants" PNNL-21167, February } \\
\text { 2012, Pacific Northwest National Laboratory, Richland, } \\
\text { WA. }\end{array}$ & $\begin{array}{l}\text { This document discusses the } \\
\text { scaling of hydrogen retention in } \\
\text { settled beds. }\end{array}$ & $\mathrm{X}$ & $\mathrm{X}$ \\
\hline 15. & $\begin{array}{l}\text { Hu, T.A., "Steady-State Flammable Gas Release Rate } \\
\text { Calculation and Lower Flammability Level Evaluation for } \\
\text { Hanford Tank Waste", RPP-5926, Rev 6., October } 2006 . \\
\text { CH2M Hill Hanford Group Inc, Richland WA. }\end{array}$ & $\begin{array}{l}\text { This document contains } \\
\text { information on the comparison } \\
\text { of measured versus predicted } \\
\text { HGR for selected waste tanks. } \\
\text { Although the document has been } \\
\text { revised, this revision is } \\
\text { referenced because later } \\
\text { revisions removed the } \\
\text { comparisons. }\end{array}$ & $\mathrm{X}$ & $\mathrm{X}$ \\
\hline 16. & $\begin{array}{l}\text { Hu, T.A. "Empirical Rate Equation Model and Rate } \\
\text { Calculations of Hydrogen Generation for Hanford Tank } \\
\text { Waste", HNF-3851, Revision 1., September, 2004. CH2M } \\
\text { Hill Hanford Group Inc, Richland WA. }\end{array}$ & $\begin{array}{l}\text { This document describes the } \\
\text { HGR model for the Hanford site. }\end{array}$ & & \\
\hline 17. & $\begin{array}{l}\text { Huckaby, J. L., Mahoney, L. A., Droppo, J. G., Meacham, J. } \\
\text { E., ” Overview of Hanford Site High-Level Waste Tank Gas } \\
\text { and Vapor Dynamics”, PNNL-14831, August 2004. Pacific } \\
\text { Northwest National Laboratory, Richland WA. }\end{array}$ & $\begin{array}{l}\text { This document contains } \\
\text { information on hydrogen } \\
\text { accumulation in settled beds. }\end{array}$ & $\mathrm{X}$ & $\mathrm{X}$ \\
\hline 18. & $\begin{array}{l}\text { King, C. M., Bryan, S. A., "Thermal and Radiolytic Gas } \\
\text { Tests on Material from Tanks 241-U-103, 241-AW-101, }\end{array}$ & $\begin{array}{l}\text { This document, along with } \\
\text { others, describes the static }\end{array}$ & $\mathrm{X}$ & \\
\hline
\end{tabular}




\begin{tabular}{|c|c|c|c|c|}
\hline $\begin{array}{c}\text { Item } \\
\text { Number }\end{array}$ & Documents Included in Literature Review & Comments & $\begin{array}{l}\text { Applicable to } \\
\text { Sealed Vessel } \\
\text { Method }\end{array}$ & $\begin{array}{l}\text { Applicable to } \\
\text { Continuous } \\
\text { Method }\end{array}$ \\
\hline & $\begin{array}{l}\text { 241-S-106, and 241-S-102 Status Report", PNNL-12181, } \\
\text { June 1999. Pacific Northwest National Laboratory, Richland } \\
\text { WA. }\end{array}$ & $\begin{array}{l}\text { methods used at PNNL to } \\
\text { measure the HGR from Hanford } \\
\text { tank waste samples. }\end{array}$ & & \\
\hline 19. & $\begin{array}{l}\text { King, C. M., Bryan, S. A., Pederson, L.R., "Thermal and } \\
\text { Radiolytic Gas Generation from Tank 241-S-102 Waste", } \\
\text { PNNL-11600, July 1997. Pacific Northwest National } \\
\text { Laboratory, Richland WA. }\end{array}$ & $\begin{array}{l}\text { This document, along with } \\
\text { others, describes the static } \\
\text { methods used at PNNL to } \\
\text { measure the HGR from Hanford } \\
\text { tank waste samples. }\end{array}$ & $\mathrm{X}$ & \\
\hline 20. & $\begin{array}{l}\text { Ledbetter, L.A., "Hydrogen Retention Rates in Slurried } \\
\text { Sludge", WSRC-TR-2004-00077, February 2004, } \\
\text { Westinghouse Savannah River Company, Aiken SC. }\end{array}$ & $\begin{array}{l}\text { This document addresses the } \\
\text { retention of hydrogen in settled } \\
\text { beds. }\end{array}$ & $\mathrm{X}$ & $\mathrm{X}$ \\
\hline 21. & $\begin{array}{l}\text { McCluskey, J. M., "222-S Laboratory Tracer Gas Analysis } \\
\text { for Helium, Hydrogen, and Methane using Gas } \\
\text { Chromatography/Thermal Conductivity Detector } \\
\text { (GC/TCD)", ATS-LT-523-163, May } 2011 .\end{array}$ & $\begin{array}{l}\text { This document describes the } \\
\text { analytical method used to } \\
\text { measure hydrogen and other } \\
\text { gases in head space samples at } \\
\text { the } 222-S \text { laboratory. A review } \\
\text { of this document and technique } \\
\text { was specifically requested. }\end{array}$ & $\mathrm{X}$ & $\mathrm{X}$ \\
\hline 22. & $\begin{array}{l}\text { McDuffie, N.G., "Flammable Gas Generation, Retention, } \\
\text { and Release in High-Level Waste Tanks Physical and } \\
\text { Chemical Models", WHC-SA-2129-FP, March } 1994 . \\
\text { Westinghouse Hanford Company, Richland, WA. }\end{array}$ & $\begin{array}{l}\text { This document contains } \\
\text { information on hydrogen } \\
\text { accumulation in settled beds. }\end{array}$ & $\mathrm{X}$ & $\mathrm{X}$ \\
\hline
\end{tabular}




\begin{tabular}{|c|c|c|c|c|}
\hline $\begin{array}{c}\text { Item } \\
\text { Number }\end{array}$ & Documents Included in Literature Review & Comments & $\begin{array}{l}\text { Applicable to } \\
\text { Sealed Vessel } \\
\text { Method }\end{array}$ & $\begin{array}{l}\text { Applicable to } \\
\text { Continuous } \\
\text { Method }\end{array}$ \\
\hline 23. & $\begin{array}{l}\text { Meacham, J.E., "Steady-State Flammable Gas Release Rate } \\
\text { Calculation and Lower Flammability Level Evaluation for } \\
\text { Hanford Tank Waste", RPP-5926, Rev 9. , October } 2009 . \\
\text { CH2M Hill Hanford Group Inc, Richland WA. }\end{array}$ & $\begin{array}{l}\text { This document contains the basis } \\
\text { for maintaining safe hydrogen } \\
\text { concentrations in the WTP } \\
\text { facility and describes the design } \\
\text { basis accident for accumulation } \\
\text { of hydrogen in settled solids } \\
\text { beds. This document also } \\
\text { describes the HGR model for the } \\
\text { WTP facility. }\end{array}$ & $\mathrm{X}$ & $\mathrm{X}$ \\
\hline 24. & $\begin{array}{l}\text { Mincher, B., "CSSX Radiolytic H2 Generation } \\
\text { ("Thermolysis") Final Report", INL/EXT-09-153402, } \\
\text { January 2009, Idaho National Laboratory, Idaho Falls, ID. }\end{array}$ & $\begin{array}{l}\text { This document describes a } \\
\text { method used to measure HGR at } \\
\text { INL used sealed, static vessels. } \\
\text { The method performed poorly } \\
\text { and was not updated. }\end{array}$ & $\mathrm{X}$ & \\
\hline 25. & $\begin{array}{l}\text { Olson, J.W., "ICD-19 - Interface Control Document for } \\
\text { Waste Feed", 24590-WTP-ICD-MG-01-019, Rev.5, April } \\
\text { 2008, River Protection Project, Richland WA. }\end{array}$ & $\begin{array}{l}\text { This document describes action } \\
\text { limits for the staged HLW and } \\
\text { LAW feeds. }\end{array}$ & & \\
\hline 26. & $\begin{array}{l}\text { Pareizs, J. M., Bibler, N. E., Fellinger, T.L., "Radiolytic } \\
\text { Hydrogen Generation and Retention in Tank } 40 \text { (Sludge } \\
\text { Batch 3) Sludge" WSRC-TR-2005-00555, January } 2006 . \\
\text { Savannah River National Laboratory, Aiken, SC. }\end{array}$ & $\begin{array}{l}\text { This document describes the } \\
\text { methods and results from } \\
\text { continuously purged mixed and } \\
\text { unmixed vessels to measure the } \\
\text { HGR from samples of high level } \\
\text { waste during vitrification } \\
\text { pretreatment processing }\end{array}$ & $\mathrm{X}$ & $\mathrm{X}$ \\
\hline
\end{tabular}




\begin{tabular}{|c|c|c|c|c|}
\hline $\begin{array}{c}\text { Item } \\
\text { Number }\end{array}$ & Documents Included in Literature Review & Comments & $\begin{array}{l}\text { Applicable to } \\
\text { Sealed Vessel } \\
\text { Method }\end{array}$ & $\begin{array}{l}\text { Applicable to } \\
\text { Continuous } \\
\text { Method }\end{array}$ \\
\hline 27. & $\begin{array}{l}\text { Person, J.C., "Effects of Oxygen Cover Gas and NaOH } \\
\text { Dilution on Gas Generation from Tank 241-SY-101 Waste", } \\
\text { WHC-SD-WM-DTR-043, May 1996, Westinghouse } \\
\text { Hanford Company, Richland WA. }\end{array}$ & $\begin{array}{l}\text { This document, along with } \\
\text { others, describes the static } \\
\text { methods used at PNNL to } \\
\text { measure the HGR from Hanford } \\
\text { tank waste samples. }\end{array}$ & $\mathrm{X}$ & \\
\hline 28. & $\begin{array}{l}\text { Poloski, A.P, Arm, S.R., Bredt, O.P, Calloway, T.B., Onishi, } \\
\text { Y, Peterson, R.A., Smith, G.L., Smith, H.D.,'Final Report: } \\
\text { Technical Basis for HLW Vitrification Stream Physical and } \\
\text { Rheological Property Bounding Conditions", WTP-RPT- } \\
\text { 112, Rev 0., January 2006. Bechtel National Inc., Richland } \\
\text { WA. }\end{array}$ & $\begin{array}{l}\text { This document describes } \\
\text { rheological property design } \\
\text { requirements for the HLW waste } \\
\text { feed. }\end{array}$ & & \\
\hline 29. & $\begin{array}{l}\text { Scogin, J. H., Crapse, K. P., “Task Technical and Quality } \\
\text { Assurance Plan for Gas Generation, Retention, and Release } \\
\text { Study”, SRNL-RP-2011-01369, August 2011, Savannah } \\
\text { River Technology Center, Aiken, SC. }\end{array}$ & $\begin{array}{l}\text { This document describes testing } \\
\text { to be performed to evaluate } \\
\text { retention of hydrogen gas in } \\
\text { settled beds and scaling of the } \\
\text { results }\end{array}$ & $\mathrm{X}$ & $\mathrm{X}$ \\
\hline 30. & $\begin{array}{l}\text { Sherwood, D.J. and Stock, L.M.,"Modifying the Hu } \\
\text { Correlation to Predict Hydrogen Formation in the Hanford } \\
\text { Waste Treatment Plant and Immobilization Plant" 24590- } \\
\text { WTP-RPT-RT-04-0002, October 2004, Richland, WA. }\end{array}$ & $\begin{array}{l}\text { This document describes the } \\
\text { HGR model as modified for use } \\
\text { in the WTP. }\end{array}$ & & \\
\hline
\end{tabular}




\section{Appendix B: Reviewed Documents Excluded from Evaluation}

Documents reviewed but not included as part of this evaluation are listed below. These documents typically discuss measurement of HGR in simulants versus radioactive tests and were excluded because they did not contain information supplemental to the radioactive tests or they were summary documents that did not contain information on the experimental methods.

\begin{tabular}{|c|l|l|}
\hline $\begin{array}{c}\text { Item } \\
\text { Number }\end{array}$ & \multicolumn{1}{|c|}{ Reviewed Documents Excluded from Evaluation } & Comments \\
\hline 1. & $\begin{array}{l}\text { Bibler, N.E., Crawford, C.L., Biddle, C.R., "Results of Scoping Studies for } \\
\text { Determining Radiolytic Hydrogen Production from Moist CST and CST } \\
\text { Slurries", WSRC-RP-98-01143, October 1998, Westinghouse Savannah River } \\
\text { Company, Aiken SC. }\end{array}$ & \\
\hline 2. & $\begin{array}{l}\text { Bradley, R.F., "Radiolysis of Liquid Waste During Bedrock Storage", DP-1264, } \\
\text { August 1971, Savannah River Laboratory, Aiken SC. }\end{array}$ & \\
\hline 3. & $\begin{array}{l}\text { Crawford, C.L., Bibler, N.E., Bibler, J.P., "An Investigation of the Radiolytic } \\
\text { Stability of a Resorcinol-Formaldehyde Ion Exchange Resin", WSRC-MS-93- } \\
550, \text { February 1994, Westinghouse Savannah River Company, Aiken, SC. }\end{array}$ & \\
\hline 4. & $\begin{array}{l}\text { Jonah, C.D., Meisel, D., Sauer Jr., M.C., "The Radiolytic and Radiolytically } \\
\text { Induced Gas Generation in Hanford Waste Tanks", ANL/CHM/PP--77923, } \\
\text { Argonne National Laboratory, Argonne, Illinois. }\end{array}$ & \\
\hline 5. & $\begin{array}{l}\text { Meehan, J.L., "M-3 Gas Release in Newtonian Pulse Jet Mixer (PJM) Mixed } \\
\text { Vessels", 24590-WTP-RPT-PET-10-007, February 2010, River Protection } \\
\text { Project, Richland WA. }\end{array}$ & \\
\hline 6. & \begin{tabular}{l} 
Meisel, D., Jonah, C.D., Kapoor, S., Mathson, M.S., Sauer Jr., M.C., "Radiolytic \\
\hline
\end{tabular} & \\
\hline
\end{tabular}




\begin{tabular}{|c|c|c|}
\hline $\begin{array}{c}\text { Item } \\
\text { Number }\end{array}$ & Reviewed Documents Excluded from Evaluation & Comments \\
\hline & $\begin{array}{l}\text { and Radiolytically Induced Generation of Gases from Synthetic Wastes", ANL- } \\
\text { 93/43, October 1993, Argonne National Laboratory, Argonne, Illinois. }\end{array}$ & \\
\hline 7. & $\begin{array}{l}\text { Meisel, D., Sauer Jr., M.C., Jonah, C.D., Diamond, H., Mathson, M.S., } \\
\text { Barnabas, F., Cerny, E., Cheng, Y., "Radiolytic and Radiolytically Induced } \\
\text { Generation of Gases in Simulated Waste Solutions", ANL/CCP/PP--74531, } \\
\text { February 1992, Argonne National Laboratory, Argonne, Illinois. }\end{array}$ & \\
\hline 8. & $\begin{array}{l}\text { Pederson, L. R., Bryan, S. A., "Status and Integration of Studies of Gas } \\
\text { Generation in Hanford Wastes", PNNL-11297, October 1996. Pacific Northwest } \\
\text { National Laboratory, Richland WA. }\end{array}$ & \\
\hline 9. & $\begin{array}{l}\text { Pederson, L. R., Strachan, D. M., "Status and Integration of the Gas Generation } \\
\text { Studies Performed for the Hydrogen Safety Program - FY } 1992 \text { Annual Report", } \\
\text { PNL_-8523, February 1993. Pacific Northwest Laboratory, Richland WA. }\end{array}$ & \\
\hline 10. & $\begin{array}{l}\text { Peterson, R.A., Swingle, R.F., "Hydrogen Retention and Release Summary from } \\
\text { Tank 48H from September } 1995 \text { to October 1996" WSRC-TR-97-0043, } \\
\text { February 1997. Savannah River Technology Center, Aiken, SC. }\end{array}$ & \\
\hline 11. & $\begin{array}{l}\text { Peurrung, L.M., Mahoney, L.A., Stewart, C.W., Gauglitz, P.A., Pederson, L.R., } \\
\text { Bryan, S.A., Shepard, C.L., "Flammable Gas Issues in Double-Contained } \\
\text { Receiver Tanks", PNNL-11836, Rev. 2, August 1998, Pacific Northwest } \\
\text { National Laboratory, Richland, WA. }\end{array}$ & \\
\hline 12. & $\begin{array}{l}\text { Sinkov, S.I., Delegard, C.H., Schmidt, A.J., "Mitigation of Hydrogen Gas } \\
\text { Generation from the Reaction of Water with Uranium Metal in K Basin Sludge", } \\
\text { PNNL-19135, January 2010. Pacific Northwest National Laboratory, Richland } \\
\text { WA. }\end{array}$ & $\begin{array}{l}\text { This study included measurements of } \\
\text { hydrogen generation from solutions } \\
\text { containing uranium metal, but the } \\
\text { experimental approach was not suitable for }\end{array}$ \\
\hline
\end{tabular}




\begin{tabular}{|c|l|l|}
\hline $\begin{array}{c}\text { Item } \\
\text { Number }\end{array}$ & \multicolumn{1}{|c|}{ Reviewed Documents Excluded from Evaluation } & Comments \\
\hline 13. & $\begin{array}{l}\text { Stock, L. M., "The Chemistry of Flammable Gas Generation", RPP-6664, } \\
\text { October 2000, CH2M Hill Hanford Group, Richland, WA. }\end{array}$ & the waste qualification work. \\
\hline 14. & $\begin{array}{l}\text { Vinson, D.W., Deible, R.W., Sindelar, R.L., "Evaluation of Hydrogen } \\
\text { Generation from Radiolysis from Breached Spent Fuel", WSRC-MS-2002- } \\
\text { 00728, September 2002, Westinghouse Savannah River Company, Aiken, SC. }\end{array}$ & \\
\hline 15. & $\begin{array}{l}\text { Walker, D.D., Crawford, C.L, Bibler, N.E., " Radiolytic Bubble Formation and } \\
\text { Level Changes in Simulated High-Level Waste Salts and Sludges - Application } \\
\text { to Savannah River Site and Hanford Storage Tanks", WSRC-MS-93-535, } \\
\text { February 1994, Westinghouse Savannah River Company, Aiken, SC. }\end{array}$ & \\
\hline
\end{tabular}


SRNL-STI-2012-00511

Revision 0

\section{Appendix C. Review of HGR Models for Tank Waste and Process Streams}

Although the measurement of hydrogen generation rate during waste qualification is required by the WTP, models have been developed and are used at SRS to determine hydrogen generation from tank wastes and process streams. These models are described in the sections below.

\section{Review of HGR Models for Tank Waste}

The mechanisms of hydrogen generation and associated reactions from Hanford waste have been studied and documented by numerous research organizations as shown by the number of organization represented in the list of references in Appendix A and Appendix B. A comprehensive model of hydrogen generation has been developed from these studies to allow expected hydrogen generation rates to be determined for Hanford waste [Meacham, 2009 and Sherwood, 2004].

Hydrogen generated by the waste has three primary sources: radiolytic hydrogen as a result of radiolysis of water and organics, thermal (or chemical reaction) hydrogen from reactions of organic species in the waste, and corrosion reactions between the waste and storage vessels, as shown in Equation 1.

$\mathrm{HGR}=\mathrm{HGR}_{\mathrm{thm}}+\mathrm{HGR}_{\mathrm{rad}}+\mathrm{HGR}_{\text {corr }}$

Each portion of the equation above is described in more detail below with the exception of HGR $_{\text {corr }}$. It is expected that the HGR from corrosion will be minimal at WTP as all vessels are stainless steel. In addition, the measurement methods typically used to determine HGR are designed to avoid corrosion during the study and would not include any hydrogen expected from corrosion of vessel components. Therefore, further discussions for HGR in WTP will exclude the corrosion term.

The hydrogen generation from thermal reactions in the waste is described by an Arrhenius equation as shown below. As shown in the equation, total organic carbon is the primary driver for thermal hydrogen generation, but aluminum species play a role. Thermal hydrogen is typically minimal at room temperature, but can be as significant as radiolytic hydrogen at elevated temperatures.

$\left.\mathrm{HGR}_{\mathrm{thm}}=\mathrm{a}_{\mathrm{thm}} \times\left(\mathrm{r}_{\mathrm{f}} \times[\mathrm{TOC}]\right) \times\left[\mathrm{Al}^{+3}\right]^{0.4} \times \mathrm{L}_{\mathrm{f}} \times \exp ^{(-\mathrm{E}}{ }_{\text {thm }}{ }^{/ \mathrm{RT}}\right)$

Where:

$\mathrm{E}_{\text {thm }}=\quad 89.6 \mathrm{~kJ} / \mathrm{mole}$, the activation energy for the thermal reaction

$\mathrm{a}_{\mathrm{thm}}=\quad 3.94 \mathrm{E}+09$ moles $/ \mathrm{kg}$-day, pre-exponential factor of the thermal rate

$\mathrm{r}_{\mathrm{f}}=\quad 0.6$ for DSTs and 0.3 for SSTs (dimensionless), the total organic carbon reactivity coefficient. The 0.3 for SSTs is an average value from the tanks tested. If tank has a high fraction of energetic organic compounds, $\mathrm{r}_{\mathrm{f}}$ can be adjusted to as high as 0.6 .

$\mathrm{R}=\quad 8.314 \mathrm{~J} / \mathrm{mole}-\mathrm{K}$, gas constant

$[\mathrm{TOC}]=\quad$ total organic carbon concentration in the liquid waste, $\mathrm{wt} \%$

Note: Insoluble energetic organic compounds (excluding oxalate) in the solid layer should be considered case by case when data is available

$\left[\mathrm{Al}^{+3}\right]=\quad$ aluminum ion concentration in liquid waste, $\mathrm{wt} \%$ 
$\mathrm{L}_{\mathrm{f}}=\quad$ liquid weight fraction in the waste, dimensionless

$\mathrm{T}=\quad$ temperature of waste, $\mathrm{K}$

Hydrogen generation from radiolysis of water and organic is modeled by the equation below.

$\mathrm{HGR}_{\mathrm{rad}}=\left[\left(\mathrm{G}_{(\mathrm{H} 2 \mathrm{O})^{\beta / \gamma}}+\mathrm{G}_{(\mathrm{org})}{ }^{\beta / \gamma}\right) \times \mathrm{H}^{\beta / \gamma}+\left(\mathrm{G}_{(\mathrm{H} 2 \mathrm{O})^{\alpha}}+\mathrm{G}_{(\mathrm{org})}{ }^{\alpha}\right) \times \mathrm{H}^{\alpha}\right] \times \mathrm{L}_{\mathrm{f}} \times \mathrm{CF}$

The "G" values for the water and organics are equations as shown below. Hydrogen generation from radiolysis of water is a function of the nitrate, nitrite, and sodium molarity of the waste and is independent of temperature. Hydrogen from radiolysis of organic species is a function of organic concentration and temperature.

$$
\begin{aligned}
\mathrm{G}_{\left(\mathrm{H}_{2}\right)_{\mathrm{ORG}}} & =\mathrm{a}_{\mathrm{rad}} \times \exp ^{\left(-\mathrm{E}_{\mathrm{rad}} / \mathrm{RT}\right)} \times\left(\mathrm{r}_{\mathrm{f}} \times[\mathrm{TOC}]\right) \\
\mathrm{G}_{\left(\mathrm{H}_{2}\right)_{\mathrm{H}_{2} \mathrm{O}}} & =\frac{0.32}{1+2.4\left[\mathrm{NO}_{3}^{-}\right]+0.62\left[\mathrm{NO}_{2}^{-}\right]+0.31\left[\mathrm{Na}^{+}\right]_{\mathrm{ex}}^{2}}+\frac{0.13}{1+139\left[\mathrm{NO}_{3}^{-}\right]+54\left[\mathrm{NO}_{2}^{-}\right]} \\
\mathrm{G}_{\left(\mathrm{H}_{2}\right)_{\mathrm{ORG}}}{ }^{\alpha} & =0.5 \times \mathrm{a}_{\mathrm{rad}} \times \exp ^{\left(-\mathrm{E}_{\mathrm{rad}} / \mathrm{RT}\right)} \times \mathrm{r}_{\mathrm{f}} \times[\mathrm{TOC}] \\
\mathrm{G}_{\left(\mathrm{H}_{2}\right)_{\mathrm{H}_{2} \mathrm{O}}{ }^{\alpha}} & =\frac{1.05}{1+2.4\left[\mathrm{NO}_{3}^{-}\right]+0.63\left[\mathrm{NO}_{2}^{-}\right]}+\frac{0.35}{1+3900\left[\mathrm{NO}_{3}^{-}\right]+1400\left[\mathrm{NO}_{2}^{-}\right]}
\end{aligned}
$$

$\mathrm{E}_{\mathrm{rad}}=\quad 48.8 \mathrm{~kJ} / \mathrm{mole}$, activation energy in organic radiolysis, $\mathrm{G}$

$\mathrm{a}_{\mathrm{rad}}=\quad 1.11 \mathrm{E}+07 \mathrm{~Hz} / 100 \mathrm{eV}$, the pre-exponential term in organic radiolysis, $\mathrm{G}$

$\mathrm{r}_{\mathrm{f}}=\quad 0.6$ for DSTs and 0.3 for SSTs (dimensionless), the total organic carbon reactivity coefficient. The 0.3 for SSTs is an average value from the tanks tested. If tank has a high fraction of energetic organic compounds, $\mathrm{r}_{\mathrm{f}}$ can be adjusted to as high as 0.6 .

$[\mathrm{TOC}]=$ total organic carbon concentration in the liquid waste, $\mathrm{wt} \%$ Note: Insoluble energetic organic compounds (excluding oxalate) in the solid layer should be considered case by case when data is available

$\left[\mathrm{Na}^{+}\right]_{\mathrm{ex}}=$ concentration of sodium minus nitrate and nitrite concentration in liquid waste, moles $/ \mathrm{L}$

$\left[\mathrm{NO}_{2}^{-}\right]=$Nitrite ion concentration, moles/L

$\left[\mathrm{NO}_{3}{ }^{-}\right]=$Nitrate ion concentration, moles/L

$\mathrm{R}=\quad 8.314 \mathrm{~J} /$ mole-K, gas constant

$\mathrm{T}=\quad$ temperature of waste, $\mathrm{K}$

$\mathrm{CF}=\quad$ conversion factor from $\mathrm{Hz}-\mathrm{watt} / 100 \mathrm{eV}-\mathrm{kg}$ to moles/kg-day

A review of model HGR rates for various waste tanks versus measured values has been performed, as shown in Table D- 1. The authors concluded that the model was adequate since the only vessels that were significantly under predicted by the model had very low HGR values. For tanks with very low HGR, the model may have been off by a large percentage, but the absolute error was small. For example, Tank 241-U-I07 had the lowest ratio between model and the measured value, but the absolute error was only 15 L/day. This point is illustrated by plotting the data, as shown in Figure D- 1 and Figure D- 2. Excellent agreement between the data and the model is evident although a small amount of non-conservatism is noted since some data points are to the left of the unity line. 
It should be noted that the NFPA standard recognizes that the calculated hydrogen value has more error than a measured value; thus the vapor space must be kept at $25 \%$ of the LFL when using a calculated concentration while the vapor space may be maintained at $67 \%$ of the LFL if the hydrogen concentration is measured with online instrumentation. In addition, WTP has established purge rates to maintain the hydrogen concentration at $12.5 \%$ of the LFL at the maximum expected hydrogen generation rates.

Table D- 1. Comparison of Model Results to Measured HGR

\begin{tabular}{|c|c|c|c|}
\hline Tank & Model & Measured & Ratio \\
\hline & HGR (L/day) & HGR (L/day) & \\
\hline 241-AN-101 & 7 & 10 & 0.69 \\
\hline 241-AN-103 & 186 & 195 & 0.95 \\
\hline 241-AN-104 & 227 & 104 & 2.17 \\
\hline 241-AN-105 & 211 & 125 & 1.68 \\
\hline 241-AN-107 & 447 & 214 & 2.09 \\
\hline 241-AW-101 & 146 & 129 & 1.12 \\
\hline 241-AY-102 & 859 & 691 & 1.24 \\
\hline 241-AZ-101 & 1,144 & 385 & 2.97 \\
\hline 241-AZ-102 & 1,190 & 775 & 1.54 \\
\hline 241-SY-101 & 2,441 & 993 & 2.45 \\
\hline 241-SY-102 & 40 & 30 & 1.34 \\
\hline 241-SY-103 & 149 & 145 & 1.02 \\
\hline 241-A-101 & 231 & 87 & 2.65 \\
\hline 241-C-104 & 105 & 90 & 1.16 \\
\hline 241-C-106 & 664 & 368 & 1.8 \\
\hline 241-S-102 & 51 & 67 & 0.77 \\
\hline 241-SX-101 & 27 & 17 & 1.59 \\
\hline 241-SX-103 & 124 & 52 & 2.4 \\
\hline 241-SX-104 & 53 & 10 & 5.23 \\
\hline 241-SX-105 & 236 & 197 & 1.2 \\
\hline 241-SX-106 & 63 & 50 & 1.25 \\
\hline 241-U-102 & 43 & 45 & 0.96 \\
\hline 241-U-103 & 60 & 60 & 1 \\
\hline 241-U-105 & 56 & 65 & 0.86 \\
\hline 241-U-106 & 46 & 27 & 1.7 \\
\hline 241-U-107 & 19 & 34 & 0.57 \\
\hline 241-U-108 & 39 & 57 & 0.67 \\
\hline 241-U-109 & 22 & 29 & 0.77 \\
\hline
\end{tabular}


SRNL-STI-2012-00511

Revision 0

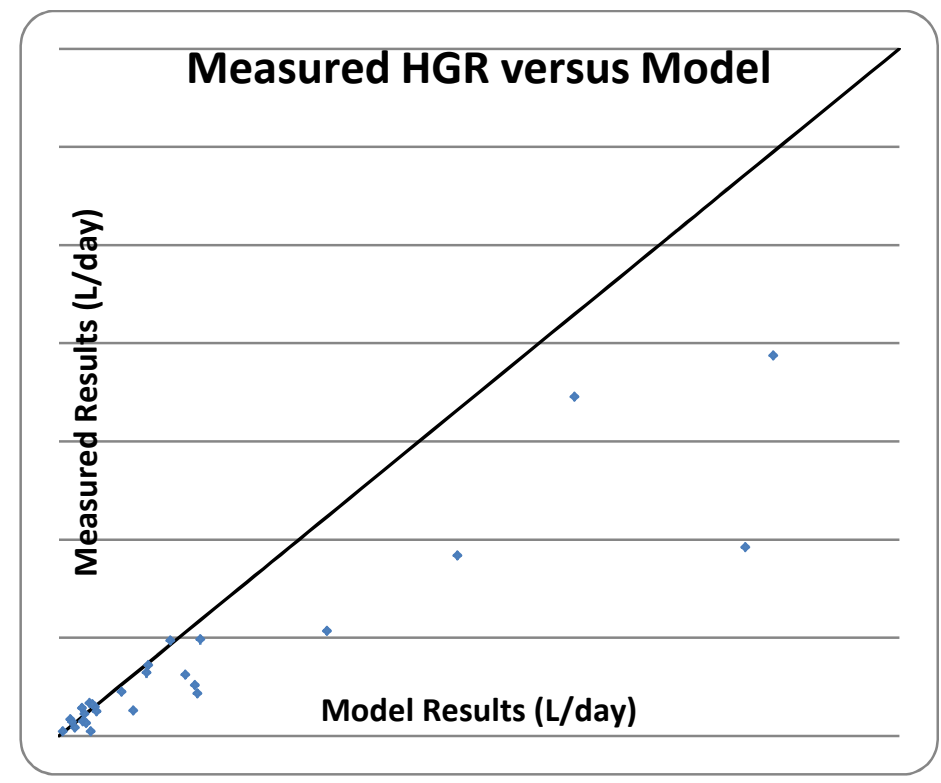

Figure D- 1. HGR Measured versus Model Results

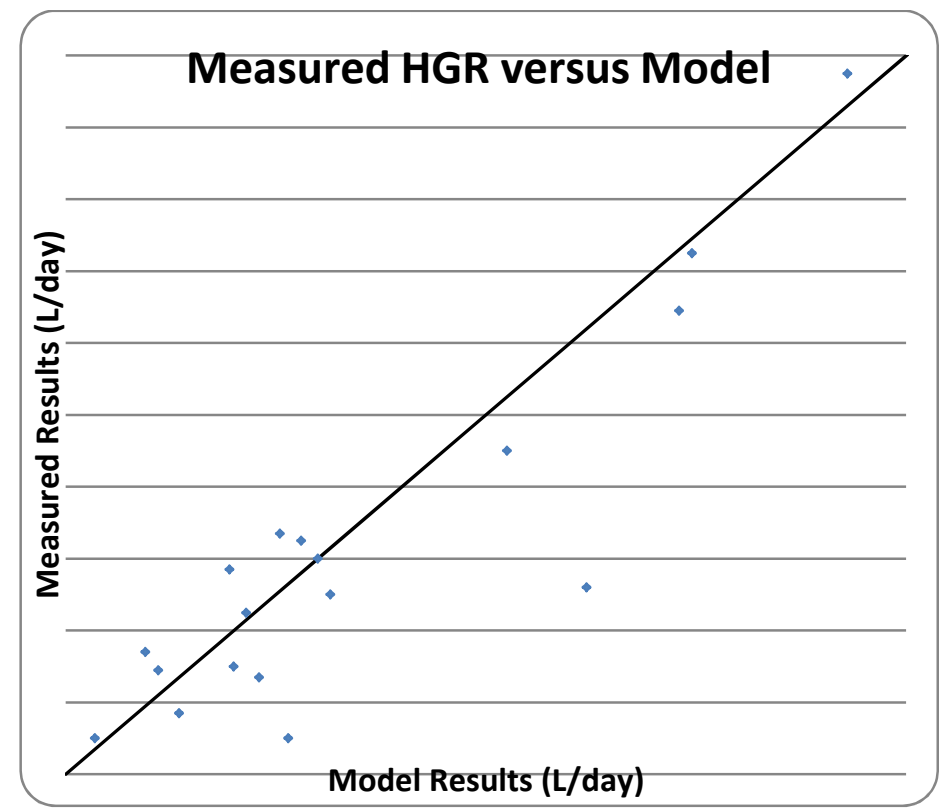

Figure D- 2. HGR Measured versus Model Results (Low End)

In addition to the reviews above, an evaluation was conducted to compare the radiolysis models used at Hanford to the models used at SRS. Both models were shown to be conservative in predicting HGR from SRS waste. This result was not unexpected as both models have been shown to be both conservative and robust at each site [Crawford, 2004]. 
The current HGR model has been reviewed and compared to field measurements of the hydrogen generation in a number of varying waste tanks at Hanford. The model compared very well or overpredicted to the field measurement with the exception of selected tanks with very low generation rates. In addition, the model has been used to calculate expected HGR values for each tank in the WTP processed and the associated times to reach the Lower Flammability Limit (LFL). It is expected that the measured HGR from the waste qualification studies will further confirm the validity of the models for the Hanford waste.

\section{Review of Applicability of HGR Models for WTP Process Streams}

The HGR model described above was developed for the waste as stored in the tank farms. Reviews have been conducted to determine if the HGR model is still applicable at various stages in the WTP [Bryan, 2004]. These studies indicated that the HGR model was unaffected by most of the compositional differences in the WTP process streams versus the tank farm untreated waste. Three areas were noted where the HGR model needed to be updated. As a result, additional work was performed and the models were updated to include a term for alpha radiolysis and water radiolysis was separated from organic radiolysis. The model was not adjusted for the impact of oxygen on HGR as the model was shown to be conservative for those conditions, although additional work was recommended [Hu, 2004]. The changes to the HGR model for use in the WTP have been documented [Sherwood and Stock, 2004]. Later reviews of the HGR method confirm the acceptability of the HGR model for use at WTP [Duncan, 2009]. The overall results from these studies are illustrated in Figure D- 3. 
SRNL-STI-2012-00511

Revision 0

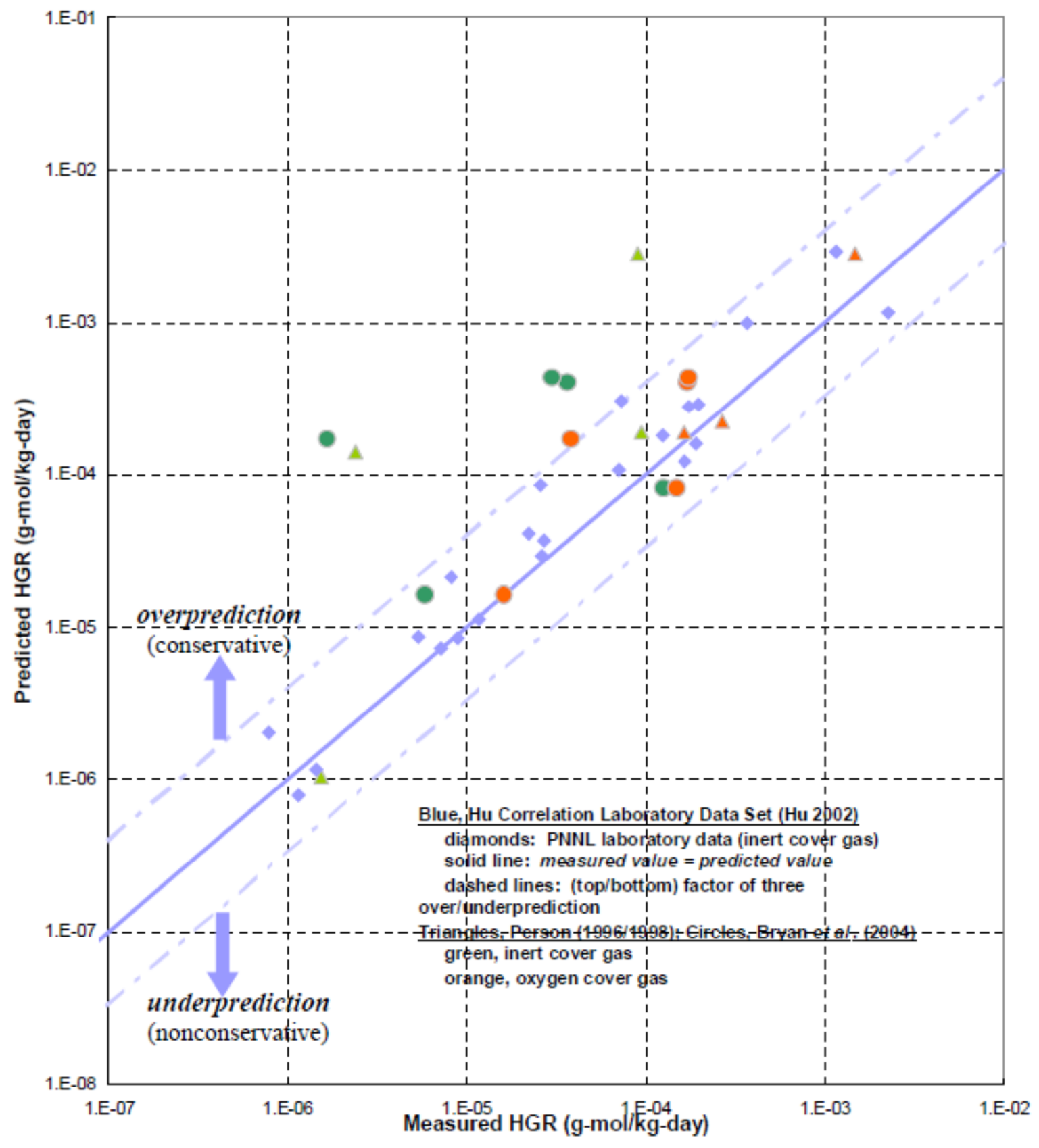

Figure D- 3. Predicted versus Measured HGR for the WTP HGR Correlation 